\title{
Biomarkers in Multiple Sclerosis
}

\author{
Anu Paul, ${ }^{1,3}$ Manuel Comabella, ${ }^{2,3}$ and Roopali Gandhi ${ }^{1,3}$ \\ ${ }^{1}$ Department of Neurology, Ann Romney Center for Neurological Diseases, Brigham and Women's Hospital, \\ Boston, Massachusetts 02115 \\ ${ }^{2}$ Department of Neurology, MS Centre of Catalonia, Vall d'Hebron University Hospital, Barcelona 08035, Spain \\ Correspondence: rgandhi@rics.bwh.harvard.edu
}

\begin{abstract}
Multiple sclerosis (MS) is a chronic neurodegenerative autoimmune disease with a complex clinical course characterized by inflammation, demyelination, and axonal degeneration. Diagnosis of MS most commonly includes finding lesions in at least two separate areas of the central nervous system (CNS), including the brain, spinal cord, and optic nerves. In recent years, there has been a remarkable increase in the number of available treatments for MS. An optimal treatment is usually based on a personalized approach determined by an individual patient's prognosis and treatment risks. Biomarkers that can predict disability progression, monitor ongoing disease activity, and assess treatment response are integral in making important decisions regarding MS treatment. This review describes MS biomarkers that are currently being used in clinical practice; it also reviews and consolidates published findings from clinically relevant potential MS biomarkers in recent years. The work also discusses the challenges of validating and application of biomarkers in MS clinical practice.
\end{abstract}

\section{WHY WE NEED BIOMARKERS IN MS}

Misina ultiple sclerosis (MS) is a chronic neurodegenerative autoimmune disease with a complex clinical course characterized by inflammation, demyelination, and axonal degeneration (Weiner 2004; Compston and Coles 2008). It is estimated that over two million people worldwide and approximately 400,000 people in the United States suffer from MS. There is much debate about the etiology of the disease; however, both genetic predisposition and environmental triggers are known to be responsible for the development of MS (Nylander and Hafler 2012).
Diagnosing MS is complex and most commonly includes finding evidence of lesions in a minimum of two areas of the central nervous system (CNS), including the brain, spinal cord, and optic nerves, along with evidence that the insult occurred at two different time points either by magnetic resonance imaging (MRI) or clinical history (Miller et al. 2008). In addition, other tests are performed to rule out differential diagnoses, including infectious, neoplastic, congenital, metabolic or vascular diseases, or nonMS inflammatory diseases. Due to its clinical need, the biomarker research in MS is very active but only a few of these studies have advanced into the validation stage and been translated

${ }^{3}$ These authors contributed equally to this article.

Editors: Howard L. Weiner and Vijay K. Kuchroo

Additional Perspectives on Multiple Sclerosis available at www.perspectivesinmedicine.org

Copyright (C) 2019 Cold Spring Harbor Laboratory Press; all rights reserved; doi: 10.1101/cshperspect.a029058

Cite this article as Cold Spring Harb Perspect Med 2019;9:a029058 
A. Paul et al.

into the clinic today (Shaw et al. 1995; Tumani et al. 2009; Teunissen et al. 2011, 2015; Ziemann et al. 2011; Stangel et al. 2013; Comabella and Montalban 2014; Gandhi 2015). This review provides a background on biomarkers and consideration for their development followed by a comprehensive overview of biomarkers studied in MS.

\section{BIOMARKERS DEFINITION}

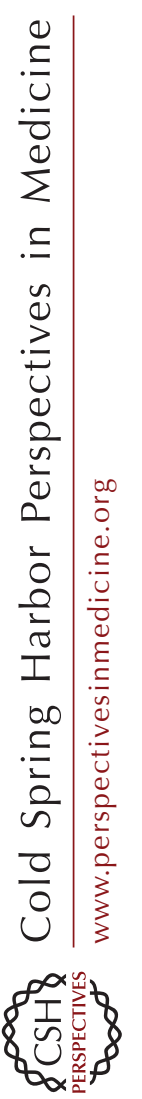

In 1998, the National Institutes of Health (NIH) defined biomarkers as "a characteristic that is objectively measured and evaluated as an indicator of normal biological processes, pathogenic processes, or pharmacologic responses to therapeutic intervention" (Biomarkers Definitions Working Group 2001). Further, the International Program on Chemical Safety, the World Health Organization (WHO), the United Nations, and the International Labor Organization jointly defined a biomarker as "any substance, structure, or process that can be measured in the body or its products and influence or predict the incidence of outcome or disease." This broader definition included effects of treatments, interventions, and environmental exposure, such as chemicals or nutrients. A WHO report on the validity of biomarkers states that a true biomarker includes "almost any measurement reflecting an interaction between a biological system and a potential hazard, which may be chemical, physical, or biological. The measured response may be functional and physiological, biochemical at the cellular level, or a molecular interaction" (World Health Organization 1993). Therefore, biomarkers can either be a substance measured in body fluids like blood or urine, or it could be the measurement of a parameter such as blood pressure or brain activity. Biomarkers in MS are crucial as they can be helpful in an early diagnosis, which enables better patient care and disease management. In addition, during the development and implementation of various treatments, it is important to have biomarkers that can help in disease diagnosis, patient stratification, and in objectively monitoring progression and response to treatment (Shi et al. 2009).

\section{CONSIDERATIONS AND CHALLENGES IN THE VALIDATION AND APPLICATION OF MS BIOMARKERS TO CLINICAL PRACTICE}

A good MS biomarker should meet with at least the following characteristic features so that it could be effectively translated into the clinical setting. It should (1) be easily and reliably measured, using precise and robust tests across multiple locations, (2) have high sensitivity and specificity, (3) correlate to the disease biology or pathogenesis such as the inflammatory activity, the degree of neurodegeneration, demyelination, or remyelination, and (4) be cost effective.

The biomarker development path is mostly comprised of two major steps: the discovery and the validation. The discovery phase usually involves analysis of a limited number of samples from well-classified subjects mostly using omic technologies. Since sample size in the discovery phase is usually small, robust statistical methods and careful replication of these results is needed in an independent cohort to further validate the biomarker's findings. Multiple validations are needed to translate a biomarker from the bench to the bedside.

In the following sections, we will discuss important considerations for a successful biomarker development program.

\section{Biobanking}

A biobank is an entity that collects, processes, stores, and distributes biospecimens, and records their associated patient information (Liu and Pollard 2015). Biospecimens could include samples like blood, tissue, bone marrow, cerebrospinal fluid (CSF), urine, and other body fluids, etc. Sample collection, preparation, and storage procedures play an important role when identifying the biomarker candidates (Gudewill et al. 1992; Clowes et al. 2002; Rababah et al. 2012; Nikula et al. 2013) and these preanalytical factors might account for up to $68 \%$ of total laboratory errors (Plebani 2006). Thus, it is important that the strict guidelines and standard operating procedures are used for biospecimen collection, preparation, and storage. Expertise in 
data-management technology is required for biobank operation and management.

\section{Study and Experimental Design}

Poor study and experimental design could reduce the generalizability of the candidate biomarkers in MS. A good study design will include multiple validations using well-defined independent patient cohorts so that potential biomarker candidate/s can be translated into clinically applicable biomarkers. A major limitation with MS biomarker research is the heterogeneity of the selected patients and controls as a result of unclear definitions of their inclusion and exclusion criteria (Comabella and Martin 2007; Teunissen et al. 2013). The other common challenges in biomarker research are the scarcity of well-defined patient cohorts (Sawcer 2008) and failed reproducibility of results across different locations.

\section{Profiling Platforms for Biomarker Discovery}

The high-throughput profiling platforms for biomarker discovery include genomics, epigenomics, transcriptomics, and proteomics. The use of these next-generation technologies has led to the faster search for biomarkers, but the generation of huge datasets is not very meaningful if it is not replicated in an independent study or does not identify already-known disease-related variables. Thus far, data generated by omics studies have not closely paralleled the data collected by focused studies of specific gene transcription and protein changes (Mellick et al. 2010). Advances are also needed to simplify the bioinformatics process to analyze and interpret the acquired data, using highthroughput sequencing platforms (Deininger et al. 2008; Franck et al. 2009). In addition, the biomarker findings from the omic studies should be replicated using a simple measure like enzyme-linked immunosorbent assay (ELISA) or quantitative polymerase chain reaction (PCR) for its easy translation into clinical settings.

\section{Specificity of the Biomarker}

Careful consideration regarding the specificity of the proposed biomarker candidate should be taken while validating biomarkers for a particular disease. For instance, MS biomarker candidates such as MMP9 and osteopontin are also noted to be dysregulated in other chronic inflammatory and autoimmune diseases (Ram et al. 2006; Lund et al. 2009). Myelin basic protein (MBP) is another nonspecific MS biomarker candidate, which is detectable in other neurological disorders such as ischemic processes and infectious diseases (Whitaker et al. 1980, 1994). The required specificity and sensitivity of a given test depends on its clinical application.

\section{Correlation to Clinically Relevant End Points}

A clinical end point is a clinically meaningful measure of how a patient feels, functions, or survives. Clinical end points should ideally capture all the aspects of therapeutic benefits. In MS, the use of relapse rate as a clinical end point to assess disease activity might not be appropriate because it does not show subclinical relapses (Comabella and Montalban 2014). Similarly, the poor ability of the Expanded Disability Status Scale (EDSS) (Cohen et al. 2012) to discriminate true disease progression from the relapse-dependent accumulation of disability is not very accurate (Comabella and Montalban 2014).

\section{CLASSIFICATION OF BIOMARKERS}

Biomarkers can be classified based upon their ability to predict, diagnose, correlate with disease, and response to treatment. MS biomarkers classified into these categories are summarized in Figure 1 and Table 1 (modified from Comabella).

\section{Predictive Biomarkers}

Predictive biomarkers could help potentially identify individuals at risk of developing MS. These biomarkers would ideally be measured in neurologically asymptomatic individuals, mainly first-degree relatives of patients with MS or patients with high risk of MS. Risk gene 
A. Paul et al.

A

Diagnostic biomarkers

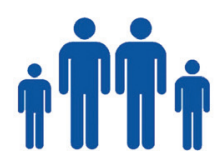

Healthy controls

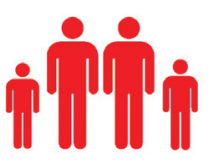

MS patients
B

Disease activity biomarkers

Clinical parameters
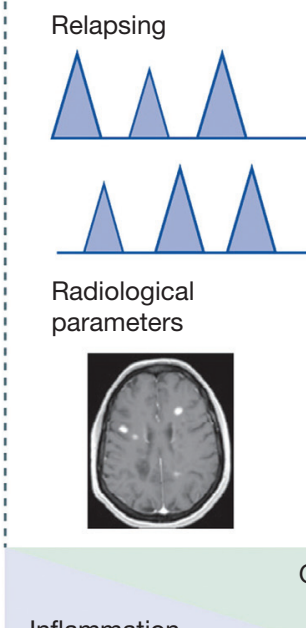

Inflammation

Demyelination

Oxidative stress

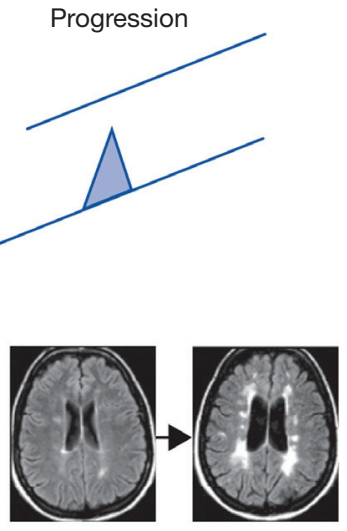

Glial activation and dysfunction Remyelination and repair

Neuroaxonal damage
C

Treatment-response biomarkers*

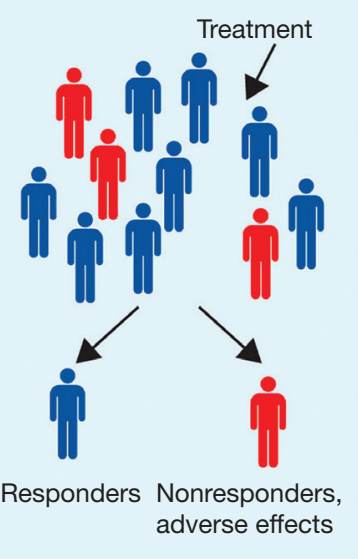

\section{Pathological processes}

Figure 1. Types of biomakers in multiple sclerosis (MS). (A) Diagnostic biomarkers comprise those that could distinguish patients with MS from healthy controls and other diseases. $(B)$ Disease activity biomarkers comprise biomarkers measured in patients with relapsing remitting courses in whom disease activity can be measured by clinical (presence of relapses and accumulation of disability) or radiological (e.g., number of gadolinium-enhancing lesions; see magnetic resonance image [MRI] on the left) parameters. This group also includes biomarkers measured in patients with progressive disease courses such as primary progressive or secondary progressive disease, or patients in the transition phase between relapsing remitting and secondary progressive courses. In these patients, disease activity can be measured by the rate of disability progression or development of brain atrophy (see MRIs on the right). In patients with MS, these biomarkers will be associated with the different pathophysiological processes that have been described. $(C)$ Treatment-response biomarkers comprise biomarkers measured in patients who are receiving MS therapies. Based on clinical or radiological responses to treatments these can be grouped as responders or nonresponders (data based on Comabella and Montalban 2014).

combinations and antibodies against EpsteinBarr virus nuclear antigens (anti-EBNA) antibodies in MS are good examples of this category of biomarkers (Sundström et al. 2004).

\section{Diagnostic Biomarkers}

A diagnostic biomarker can be used to distinguish MS patients from others with neurological or autoimmune disorders, or from healthy individuals. Diagnostic biomarkers are measured in patients with neurological symptoms that are suggestive of a demyelinating disorder such as those with clinically isolated syndromes (CIS) (Nielsen et al. 2005) and radiologically isolated syndromes (RIS) (Miller et al. 2005). Ideally, these biomarkers can be helpful in combination with clinical and radiological disease diagnostic criteria to improve their sensitivity and specificity. Most of the biomarkers studied so far in MS belong to this category (Table 1). The use of diagnostic biomarkers might be 
Table 1. Comprehensive list and strength of evidence for molecular biomarkers in multiple sclerosis

\begin{tabular}{|c|c|c|}
\hline Exploratory biomarkers & Validated biomarkers & $\begin{array}{c}\text { Clinically useful } \\
\text { biomarkers }\end{array}$ \\
\hline Cytokines (D, DA, IFN- $\beta-R$, GA-R) & Anti-EBNA (P, D, DA) & Anti-NZ (NZ-R) \\
\hline Adhesion molecules (D, DA, IFN- $\beta$-R, NZ-R) & KFLC (D) & NAbs (IFN- $\beta-R)$ \\
\hline Chemokines and receptors (D, DA, IFN- $\beta-R)$ & IGM OB (D, DA, IFN- $\beta-R, N Z-R)$ & $\operatorname{IgG~OB}(\mathrm{D})$ \\
\hline MMPs and inhibitors (D, DA, IFN- $\beta-R)$ & NCAM1 (D, DA) & IgG index (D) \\
\hline Proteomics (D, DA, IFN- $\beta-R)$ & NO metabolites (D, DA) & Anti-AQP4 (D) \\
\hline Cystatin C (D) & MMP9 (D, DA, IFN- $\beta-R)$ & Anti-JC virus (NZ-R) \\
\hline microRNA (D, DA, GA-R) & $\operatorname{MBP}(\mathrm{D}, \mathrm{DA})$ & Anti-VZV (F-R) \\
\hline $\mathrm{C} 31 / \mathrm{C} 4 \mathrm{~b}(\mathrm{D}, \mathrm{DA})$ & MMP9 (D, DA, IFN- $\beta-R)$ & \\
\hline sCD146 (DA) & $\operatorname{MBP}(\mathrm{D}, \mathrm{DA})$ & \\
\hline sCD14 (D, DA) & SPP1 (D, DA) & \\
\hline sHLA I and sHLA II (D, DA, IFN- $\beta-\mathrm{R})$ & CXCL13 (D, DA) & \\
\hline sHLA-G (D) & GFAP (D, DA) & \\
\hline sNogo-A (D, DA) & BDNF (D, DA, IFN- $\beta-R$, GA-R) & \\
\hline Anti-Nogo-A (D, DA) & KCNJ10 (D) & \\
\hline Anti-MBP (D, DA) & MRZ reaction $(D, D A)$ & \\
\hline Anti-MOG (D, DA) & CHI3L1 (D, DA, NZ-R) & \\
\hline Anti-HHV6 (DA) & Complement factor $\mathrm{H}(\mathrm{DA})$ & \\
\hline Anti-proteasome (D) & Type I IFNs (DA, IFN- $\beta$-R) & \\
\hline Anti-CD46 and anti-CD59 (DA) & GPC5 (IFN- $\beta-R)$ & \\
\hline Lipocalin 2 (DA) & $\begin{array}{l}\text { HLA-DRB1*04:01, HLA-DRB* 04:08 } \\
\quad(\text { IFN- } \beta-\text {-R) }\end{array}$ & \\
\hline VEGFA (DA) & $\mathrm{IL}-17(\mathrm{D}, \mathrm{DA})$ & \\
\hline AMCase and Chit (D,DA) & $\operatorname{BAFF}(\mathrm{D}, \mathrm{DA}, \mathrm{IFN}-\beta-\mathrm{R})$ & \\
\hline Fetuin-A (D, DA, NZ-R) & TNF, IL-12, IL-23 (D, DA) & \\
\hline APRIL (DA) & GWAS genes $(\mathrm{P}, \mathrm{D})$ & \\
\hline CSF cells $(\mathrm{D}, \mathrm{DA})$ & NEFH (DA) & \\
\hline S/GPL $(P, D)$ & NEFL (D, DA, NZ-R) & \\
\hline HMGB1 (D) & $25(\mathrm{OH})$ vit $\mathrm{D}(\mathrm{P}, \mathrm{D}, \mathrm{DA}, \mathrm{IFN}-\beta-\mathrm{R})$ & \\
\hline TOB1 (D) & CD56 ${ }^{\text {bright }}$ NK cells (DC-R, IFN- $\left.\beta-R\right)$ & \\
\hline \multicolumn{3}{|l|}{ S100B and ferritin (D, DA) } \\
\hline \multicolumn{3}{|l|}{ Isoprostanes (P, D, DA) } \\
\hline \multicolumn{3}{|l|}{ Oxysterols (D, DA) } \\
\hline \multicolumn{3}{|l|}{ Pentosidine (D, DA) } \\
\hline \multicolumn{3}{|l|}{ Tau (D, DA) } \\
\hline \multicolumn{3}{|l|}{$14-3-3(\mathrm{D}, \mathrm{DA})$} \\
\hline \multicolumn{3}{|l|}{ NAA and NSE (D, DA) } \\
\hline \multicolumn{3}{|l|}{ Anti-TUb and b-TUb (D, DA) } \\
\hline \multicolumn{3}{|l|}{ Anti-NEFL (DA) } \\
\hline \multicolumn{3}{|l|}{ Neurotrophic factor (D, DA) } \\
\hline \multicolumn{3}{|l|}{ Tregs (DA) } \\
\hline \multicolumn{3}{|l|}{ KCNK5 (D, DA) } \\
\hline \multicolumn{3}{|l|}{ FGF2 and PDGF-AA (DA) } \\
\hline \multicolumn{3}{|l|}{ gMS classifier $1(\mathrm{D}, \mathrm{DA})$} \\
\hline \multicolumn{3}{|l|}{ Myeloid MVs (D, DA) } \\
\hline \multicolumn{3}{|l|}{ sAPP, A $\beta$ peptides $(D, D A)$} \\
\hline \multicolumn{3}{|l|}{ Apoptosis-related molecules (D, DA, IFN- $\beta-R)$} \\
\hline \multicolumn{3}{|l|}{ Cosignaling molecules (DA, IFN- $\beta-\mathrm{R})$} \\
\hline \multicolumn{3}{|l|}{ GWAS genes (IFN- $\beta-\mathrm{R})$} \\
\hline Candidate genes (IFN- $\beta-\mathrm{R}, \mathrm{GA}-\mathrm{R})$ & & \\
\hline
\end{tabular}


A. Paul et al.

Table 1. Continued

\begin{tabular}{lll}
\hline Exploratory biomarkers & Validated biomarkers & $\begin{array}{c}\text { Clinically useful } \\
\text { biomarkers }\end{array}$ \\
\hline CIITA (IFN- $\beta$-R) & & \\
APLA (IFN- $\beta$-R) & \\
IL-17F (IFN- $\beta$-R) & \\
ABCB1, ABCG2 (MT-R) & \\
IL-21 (AL-R) & \\
\hline
\end{tabular}

Data based on Comabella and Montalban (2014).

Biomarkers can be grouped into the categories of exploratory biomarkers (any biomarker proposed as a candidate for the disease or identified in discovery hypothesis-free studies using so-called omics technologies), validated biomarkers (biomarkers for which there is stronger evidence about their association with the disease), and clinically useful biomarkers (biomarkers routinely tested in clinical settings). The type of biomarker is indicated in parentheses.

P, Predictive biomarker; D, diagnostic biomarker; DA, disease activity biomarker; AL-R, alemtuzumab-response biomarker; DC-R, daclizumab-response biomarker; F-R, fingolimod-response biomarker; GA-R, glatiramer-acetate-response biomarker; IFN- $\beta$-R, interferon $\beta$ response biomarker; MT-R, mitoxantrone-response biomarker; NZ-R, natalizumab-response biomarker; MMP, matrix metalloprotease; C3/C4b, complement components $\mathrm{C} 3$ and $\mathrm{C} 4 \mathrm{~b}$; sCD146, soluble CD146; sCD14, soluble CD14; sHLA, soluble human leukocyte antigen; sHLA-G, soluble HLA-G; sNogo-A, soluble Nogo-A; anti-Nogo-A; anti-Nogo-A antibodies; anti-MBP, anti-myelin basic protein; anti-MOG, anti-myelin oligodendrocyte protein; anti-HHV-6, anti-human herpesvirus 6; VEGFA, vascular endothelial growth factor A; AMCase, acid mammalian chitinase; Chit, chitinase 1 (chitotriosidase); TNFSF13 (also known as APRIL), tumor necrosis factor (ligand) superfamily, member 13; S/GPL, sulphatide and glycosphingolipid antibody titers; HMGB1, high mobility group box 1; TOB1, transducer of ERRB2 1; NAA, $N$-acetyl aspartic acid; NSE, neuron-specific enolase; anti-TUb, anti-tubulin antibodies; $\beta$-TUb, $\beta$-tubulin isoforms II and III; anti-NEFL, anti-neurofilament light chain antibodies; Tregs, T-regulatory cells; KCNK5, potassium channel subfamily K member 5; FGF2, fibroblast growth factor 2; PDGF-AA, platelet-derived growth factor-AA; gMS classifier 1, anti-Glc $(\alpha \mathrm{l}, 4)$ $\operatorname{Glc}(\alpha)$ IgM antibodies; myeloid MVs, myeloid microvesicles; sAPP, soluble amyloid precursor protein; A $\beta$ peptide, amyloid $\beta$ peptide; GWAS, genome-wide association study; CIITA, class II transactivator; APLA, antiphospholipid antibodies; ABCB1, ATP-binding cassette, subfamily B, member 1; ABCG2, ATP-binding cassette, subfamily G, member 2; anti-EBNA, antibodies against Epstein-Barr virus nuclear antigens; KFLC, $\kappa$-free light chain; OB, oligoclonal bands; NCAM1, neural cell adhesion molecule 1; NO metabolites, nitric oxide and its metabolites, nitrates, and nitrites; SPP1 (also known as osteopontin), secreted phosphoprotein 1; CXCL, CXC ligand 1; GFAP, glial fibrillary acidic protein; BDNF, brain-derived neurotrophic factor; KCNJ10 (also known as KIR4.1), potassium inwardly rectifying channel, subfamily J, member 10; MRZ reaction, intrathecal humoral immune response against measles, rubella, and varicella zoster virus; CHI3L1, chitinase-3-like protein 1; GPC5, glypican-5; BAFF, B-cell activating factor; TNF, tumor necrosis factor; NEFH, human neurofi lament heavy chain; NEFL, human neurofilament light chain; $25(\mathrm{OH})$ vit $\mathrm{D}, 25$-hydroxyvitamin $\mathrm{D}$; CD56 ${ }^{\text {bright }} \mathrm{NK}$ cells, CD56 ${ }^{\text {bright }}$ natural killer cells; anti-NZ, anti-natalizumab antibodies; NAbs, neutralizing antibodies; anti-AQP4, anti-aquaporin 4 antibody; anti-JC virus, antibodies against JC virus; anti-VZV, anti-varicella zoster virus antibodies.

particularly relevant in patients with CIS to identify individuals at high risk of converting to MS.

\section{Disease Activity Biomarkers}

Disease activity biomarkers could distinguish relapsing remitting from the secondary progressive patients. In patients with MS, these biomarkers are associated with the different pathophysiological processes of the disease (Lassmann et al. 2007). For instance, markers of inflammation and oxidative stress are expected to have more important roles in the relapsing remitting phases of the disease, whereas the markers of glial dysfunction, remyelination, and axonal damage will be related to the progressive and, hence, the neurodegenerative phases of MS. This type of biomarker could also help to distinguish benign from aggressive MS disease courses. Currently, these are defined on the basis of the presence or absence of clinical activity (relapses and accumulation of disability) and radiological inflammatory activity (changes in T2-weighted and gadolinium (Gd)-enhancing lesions on MRI). Disease activity biomarkers can be used in conjunction with the clinical and radiological information to identify patients in need of treatment or to select the best treatment options. 


\section{Treatment-Response Biomarkers}

Treatment-response biomarkers are measured in patients receiving MS treatment to identify individuals at risk of treatment failure so that alternate treatment options can be considered. Pharmacokinetic and pharmacodynamic biomarkers are also included in this group and can be used to guide dose selection, dose escalation, dose combination, and safety monitoring. Another potential application of these biomarkers would be an identification of patients who might respond better to a specific drug so that personalized treatment options could be designed. With the availability of more than 10 therapeutic options for MS, it is very important to identify blood-based treatment biomarkers that could benefit patients to choose the best treatment option and to avoid unnecessary side effect accrual.

\section{Side Effect Monitoring Biomarkers}

This group includes biomarkers that identify patients at a higher risk of developing adverse side effects and therefore can aid clinicians in decisions regarding discontinuation of treatment, alternate options, and close monitoring. For instance, John Cunningham virus (JCV) antibodies are a useful biomarker for stratifying the risk of progressive multifocal leukoencephalopathy (PML) in patients treated with natalizumab (Antoniol and Stankoff 2014; Outteryck et al. 2014).

\section{CLINICALLY USED BIOMARKERS IN MS}

\section{MRI and Contrast Enhancing Lesions}

MRI remains the most important clinical tool for disease diagnosis, disease activity, and treatment response in MS.

\section{Hyperintense T2-Weighted Lesions}

The presence of white matter lesions on MRI typically indicates the progression of patients from CIS to a clinically defined MS subtype. However, the correlation between clinical dis- abilities measured by EDSS and T2-weighted white matter lesion load varies broadly in the literature (Barkhof 1999; Zivadinov and Leist 2005; Li et al. 2006; Fisniku et al. 2008).

Further studies concluded that the development of new or enlarging T2 lesions during $\beta$-interferon (IFN) treatment could serve as a predictor of poor long-term response to therapy, consequently leading to continuous progression of disability (Prosperini et al. 2009; Rio et al. 2009). Advances in MRI techniques have identified simpler ways to examine MS lesions. Gd, a paramagnetic element, can only cross the blood-brain barrier in sites of damage or inflammation. The presence of Gd-enhancing lesions on MRI in MS indicates active inflammation (Katz et al. 1993; Brück et al. 1997). The number and size of these enhancing MRI lesions are predictive of both the onset and severity of relapses (Katz et al. 1993; Smith et al. 1993; Khoury et al. 1994; Brück et al. 1997); there is limited or no correlation between Gd-enhancing lesions and cognitive decline in relapsing remitting MS (RRMS) (Rocca et al. 2015).

\section{Gray Matter Atrophy Biomarkers}

Due to some of the limitations of enhancing lesions, studies have focused on identifying diffuse gray matter damage and not just lesion load. These studies indicate a positive correlation between overall gray matter atrophy and cognitive dysfunction, which suggests gray matter atrophy and may be a useful biomarker in the prediction of clinical severity (Geurts et al. 2012). While understanding its implications over lesion load, it must be noted that double inversion recovery imaging techniques display gray matter atrophy in stages and types of MS, with higher worsening rates in secondary progressive MS (SPMS) patients (Fisher et al. 2008). Also, greater worsening rates of gray matter atrophy in CIS patients correlated with the rapid conversion to RRMS (Dalton et al. 2004).

\section{Whole Brain Atrophy Biomarkers}

Brain atrophy rate is accelerated in untreated MS patients $(0.5 \%-1 \%$ annualized decrease) com- 
A. Paul et al.

pared to healthy controls $(0.1 \%-0.3 \%)$ (De Stefano et al. 2010). Brain atrophy worsening rate at initial diagnosis has been proposed as a prognostic biomarker of future disability (Fisher et al. 2002).

\section{Spinal Cord Atrophy Biomarkers}

Atrophy in the upper cervical cord area (UCCA) is observed in progressive MS forms, which correlates well with disability progression. Therefore, UCCA atrophy in early disease stages in RRMS patients may predict poor prognosis ( $\mathrm{Ra}-$ shid et al. 2006).

MRI is a primary tool for determining efficacy in phase II MS clinical trials; nevertheless, the measures of disease severity that are currently in use reflect the inflammatory rather than the degenerative aspect of the disease. Lately, it has been proposed that T1 lesion volume and general cerebral atrophy will be used in phase II clinical trials of neuroprotective and/or reparative strategies (Barkhof et al. 2009).

\section{Oligoclonal Bands and IgG Ratio}

The diagnosis of MS, prior to the 1983 criteria, required only the occurrence of clinical symptoms. However, up to $90 \%$ of MS patients exhibit oligoclonal bands (OCBs) in the CSF (Davenport and Keren 1988), leading to the inclusion of the presence of OCBs as a biomarker in the diagnostic criteria of MS in the 1983, 2001, and 2005 McDonald criteria (Poser et al. 1983). Although OCBs were deleted from the McDonald criteria in 2010 for RRMS, they remain a criterion for the diagnosis of primary progressive MS (PPMS). The presence of oligoclonal bands in CSF is predictive of conversion from CIS to MS (Rojas et al. 2010; Kuhle et al. 2015a).

\section{JC Viral Antibody Titers}

JCV is a type of human polyoma virus commonly infecting $70 \%$ to $90 \%$ of humans. Most people acquire JCV in childhood or adolescence (Padgett and Walker 1973; Agostini et al. 1997; Shackelton et al. 2006). In immune-compro- mised individuals, the virus may reactivate and migrate to the brain where it establishes an infection of oligodendrocytes and astrocytes. This leads to PML, a severe encephalopathy, with mortality in the range of $20 \%-50 \%$. In MS, immunosuppressive medication may lead to reactivation of the latent JCV. Natalizumab is a monoclonal antibody that blocks the $\alpha 4$ integrin and therefore inhibits the T-cell migration to the CNS (Polman et al. 2006). Natalizumab is a highly effective disease-modifying agent carrying the risk to develop PML as a rare adverse event, mostly in patients treated with the drug for more than 2 years (Antoniol and Stankoff 2014). PML occurs in 3.7/1000 patients treated with natalizumab (Brew et al. 2010). Recently, a routine use of ELISA-based tests for JCV antibodies was implemented to determine whether the patient was previously infected with JCV and is therefore at risk to develop PML. Only two cases of PML have been reported in seronegative individuals (Antoniol and Stankoff 2014; Outteryck et al. 2014). JCV antibodies are thus a useful biomarker for stratifying the risk of PML. Importantly, while around $50 \%$ of MS patients are JCV antibody seropositive (Olsson et al. 2013; Outteryck et al. 2014), less than $1 \%$ are prone to develop PML (Plavina et al. 2014), and, therefore, more specific biomarkers may help in individualizing treatment strategies.

\section{Neutralizing Antibodies}

IFN- $\beta$ is the most commonly used treatment for MS. About $40 \%$ of the treated patients do not respond to this treatment (Rudick et al. 2004). Thus, it is important to find biomarkers to identify patients that would be benefited by this treatment. IFN- $\beta$ treatment induces an immunologic response by generating neutralizing antibodies that may have a negative impact on clinical and radiological disease activity, particularly when present at high and persistent titers. These neutralizing antibodies are a clinically used test to identify nonresponders (Polman et al. 2010). The drawback of this test is that it only identifies a fraction of nonresponders. 


\section{PROMISING BIOMARKER CANDIDATES IN MS}

YKL-40

YKL-40 (also known as chitinase 3-like-1 or CHI3L1) is a member of the chitinase-like glycoprotein family. It is a glial activation marker that is predominantly expressed by reactive astrocytes (Bonneh-Barkay et al. 2010; Cantó et al. 2015). It can also be expressed on activated macrophages, vascular smooth muscle cells, airway epithelia, and chondrocytes (Cantó et al. 2015). The serum levels of YKL-40 have been found to be elevated in many inflammatory conditions such as rheumatoid arthritis (Peltomaa et al. 2001), systemic lupus erythematosus (Vos et al. 2000), and inflammatory bowel diseases (Vind et al. 2003). In particular, reactive astrocytes and microglia at the rim of chronically active lesions from MS patients have a higher expression of YKL-40 (Cantó et al. 2015). Although the physiological role of YKL-40 is not known, it is hypothesized to play a role in tissue remodeling during inflammation (Bonneh-Barkay et al. 2010). Confirmatory studies from Comabella's group showed increased expression of CSF YKL-40 in CIS patients converting to MS compared to the nonconverters (Comabella et al. 2010). YKL-40 was also associated with decreased time to progression of EDSS score 3 and 6 (Martínez et al. 2015). The relation between YKL-40 expression and MRI imaging is not clear; three studies reported that YKL-40 correlated with the number of $\mathrm{Gd}+$ lesions (Correale and Fiol 2011; Cantó et al. 2015; Burman et al. 2016) and another failed to detect any correlation (Modvig et al. 2013).

\section{CXCL13}

CXCL13 is a component of the lymphoid chemokines (CXCL12, CXCL13, CCL19, and CCL21) family that regulates the migration and compartmentalization of B cells within secondary lymphoid organs in both homeostatic as well as inflammatory conditions (Cyster 2005; Okada and Cyster 2006). CXCL13 is expressed by $\mathrm{B}$-cell follicles and contributes to the germinal center formation by recruiting activated B- and follicular helper $\mathrm{CD} 4^{+} \mathrm{T}$ cells expressing its cognate receptor CXCR5 (Zotos et al. 2010; Crotty 2012; Victora and Nussenzweig 2012). Several studies show CXCL13 expression elevated in the CSF from CIS, RRMS, SPMS, and PPMS patients compared to symptomatic controls (Stilund et al. 2015) and during active disease (Festa et al. 2009). In a large cohort study where 465 MS patients were compared to healthy controls and other neurological diseases, CXCL13 expression was associated with increased relapse rate, EDSS score, and lesion burden (Khademi et al. 2011). When comparing different subtypes of MS, CSF CXCL13 levels have been found to be higher during relapses of RRMS (Khademi et al. 2011). CIS patients who converted to clinically definite MS had higher levels of CXCL13 in the CSF compared to CIS patients who did not convert (Brettschneider et al. 2010; Khademi et al. 2011). CXCL13 levels also correlated with OCBs in the $\mathrm{CSF}$, suggesting that $\mathrm{OCBs}$ and $\mathrm{CXCL13}$ may be related. However, expression of CXCL13 is probably not disease specific as patients with encephalitic viral infections also have higher levels of CXCL13 (Khademi et al. 2011).

\section{MicroRNAs (miRNAs)}

miRNAs, a class of noncoding single-stranded RNAs approximately 22 nucleotides in length, modulate gene expression following transcription by targeting messenger RNA (mRNA) degradation or by inhibiting protein translation (Ota et al. 1990; Pette et al. 1990). miRNAs play important roles in various biologic processes like proliferation, differentiation, metabolism, apoptosis, and angiogenesis (Zhu et al. 2013; Qu et al. 2014). An estimated one-third of human genes are negatively regulated at posttranscriptional levels by miRNAs (Lewis et al. 2003). Dysregulated miRNA expression and function is associated with several diseases, including neurodegeneration, cancer, and autoimmunity. They have the potential to serve as biomarkers or to suggest therapeutic target options (Esteller 2011). Several studies performed miRNA profiling in MS patients and control subjects using different sample types, including peripheral 
A. Paul et al.

blood mononuclear cells (PBMCs) (Otaegui et al. 2009; Fenoglio et al. 2011; MartinelliBoneschi et al. 2012), whole blood (Keller et al. 2009; Cox et al. 2010), and brain lesions (Junker et al. 2009). All of these studies showed miRNA expression profiles associated with MS. Of interest is the identification of a specific miRNA signature associated with MS disease relapse (Otaegui et al. 2009). This study showed dysregulation of miR-18b and miR-599 expression during a relapse and dysregulation of miR-96 levels while in remission (Otaegui et al. 2009). A study focused on measuring the expression of miRNAs with known immunological relevance, such as miR-21, miR-146a, miR-146b, miR-150, and miR-155, in PBMC from untreated MS patients compared to healthy controls (Fenoglio et al. 2011), found increased expression of miR-21, miR-146a, and miR-146b in RRMS patients compared to the healthy controls. No differences were found in both miR-150 and miR155 expression (Fenoglio et al. 2011). Another study measured miR-326 expression in PBMC and found that it correlates with disease severity in MS patients and experimental autoimmune encephalomyelitis (EAE) mice (Zahednasab and Balood 2014). In vivo, inhibition of miR326 resulted in fewer T helper (Th) 17 cells and a milder EAE, while its overexpression resulted in more Th17 cells (Du et al. 2009; Littman and Rudensky 2010; Zhang et al. 2014).

Circulating miRNA can be detected in several human body fluids, including plasma, serum, urine, and saliva (Park et al. 2009; Hanke et al. 2010) and were studied as potential biomarkers in different human diseases (Mitchell et al. 2008; Redell et al. 2010). Published and unpublished studies from the Gandhi group showed that circulating miRNAs both in serum and plasma provide biomarkers for disease diagnosis, association with disease stages, and correlation with clinical parameters like EDSS (Gandhi et al. 2013). A recent study by the same group showed that seven miRNAs differentiate MS patients from healthy controls; miR320a up-regulation was the most significantly changing serum miRNA in MS patients. They identified two miRNAs linked to disease progression, with hsa-miR-27a-3p being the most significant. Ten miRNAs correlated with EDSS of which miR.199a.5p had the strongest correlation with disability (Regev et al. 2016). A preliminary study evaluated the expression of selected miRNA (miR-let-7a, miR-92a, and miR-648a) in the MS patient's plasma during a relapse and while in remission. They found that miR-let-7 and miR-648a are significantly different in disease remission compared to the controls (Kacperska et al. 2015). In another study, it was found that miR-17-5p, miR-92, miR-193a, and miR-497 were deregulated in RRMS patients compared to the healthy subjects (Lindberg et al. 2010).

In summary, we observed a wide variety of results in terms of MS-associated miRNA obtained by different groups, which may reflect its limitations potentially because of the lack of a reliable assay platform, few patients, and the lack of strong validation using an alternative platform or set of patients. Numbers of other variables such as specimen collection, RNA extraction, RT-qPCR, data analysis, and normalization also influence miRNA results. However, the studies published to date point toward miRNAs having a role in the future of MS biomarkers. It will require considerable effort from researchers in different fields to develop consensus protocols to design proof of concept studies to identify miRNA as the MS biomarker.

\section{OTHER BIOMARKERS IN MS}

\section{KIR4.1 Antibodies}

A detailed study examining various antibody responses in patients with MS (Srivastava et al. 2012) identified IgG1 and IgG3 antibodies that bind to glial cells in human brain tissues. This glia-specific immunoreactivity was not observed in sera of patients who had other neurological disorders. The molecular target of these antibodies was potassium channel KIR4.1. This channel is specifically expressed in the end feet of astrocytes and is important for maintaining potassium and water balance. Antibodies directed against KIR4.1 were detected in the serum of 186 of 397 (47\%) patients with MS, whereas they were present in the sera of less than $1 \%$ of pa- 
tients with other neurological disorders $(n=$ 329), and not in healthy individuals. This study determined that KIR4.1 is the target of an autoantibody response in some patients with MS (Srivastava et al. 2012), but the results from this study was contradicted by many other studies that showed no differences in controls and MS patients for the presence of anti-KIR4.1 antibodies (Brickshawana et al. 2014; Nerrant et al. 2014; Brill et al. 2015; Chastre et al. 2016; Pröbstel et al. 2016). KIR4.1 expressed on astrocytes localizes with another channel, aquaporin-4 (AQP4), the target for another inflammatory, demyelinating disease: neuromyelitis optica (NMO). NMO was originally thought to be a form of MS, but the discovery of an antibody response directed against AQP4 (termed NMOIgG) suggested a distinct pathogenic process differentiating $\mathrm{NMO}$ from MS. NMO-IgG is present in $73 \%$ of patients with NMO, but absent in the serum of patients with MS (Lennon et al. 2005).

\section{TOB-1}

Studies have shown that TOB-1 polymorphisms represent an independent factor that can influence the progression from CIS to clinically definite MS (CDMS) (Corvol et al. 2008). The TOB-1 gene plays a suppressive role in T-cell proliferation, keeping autoreactive cells dormant, and its decreased expression leads toward a more intense immune response (higher percentage of Th1 and Th17 cells and a smaller percentage of T-regulatory cells).

\section{Apo-Lipoprotein E (ApoE)}

ApoE is a protein regulating lipid homeostasis. Its function is mostly related to its presence in astrocytes. $\varepsilon 4$ allele of ApoE is associated with greater risk of developing mental disorders in MS patients (Zhang et al. 2010).

\section{Myelin Basic Protein}

MBP is highly expressed on the surface of myelin and is involved in maintaining myelin structure. Increased MBP in the CSF of MS patients was an early marker suggested in MS (Cohen et al. 1976; Whitaker 1977). However, with MRI monitoring of patients, there is no clinical utility in measuring MBP levels in the CSF.

\section{CNS Neurofilaments and Glial Fibrillary Acidic} Protein (GFAP)

Neurofilaments $(\mathrm{Nfl})$ are the 10 nanometer or intermediate filaments found in neurons. CNS neurofilaments can be distinguished in neurofilament heavy, medium, and light chains and $\alpha$-internexin and they are usually released after axonal damage. Recent studies have shown that light-chain Nfl are a more consistent and solid marker in MS (Kuhle et al. 2013). Nfl levels in CSF can be measured by ELISA and are increased in both RRMS and progressive MS compared to the healthy control subjects. Although in patients with RRMS, Nfl is typically increased compared to healthy subjects, levels fluctuate consistently with clinical course and the presence of active lesions by MRI (Bielekova and McDermott 2015). Nfl has been found to be elevated at first diagnosis and in CIS, which suggests possible use as an early marker for MS (Disanto et al. 2015). In addition, a longitudinal study suggested that $\mathrm{Nfl}$ levels in the CSF could be predictive of conversion from CIS to MS within 1 year (Martínez et al. 2015). It has also been shown that Nfl levels in CSF can be predictive of disease severity, progression to SPMS (Salzer et al. 2010), and longterm physical and cognitive disability after conversion to CDMS (Modvig et al. 2015). Taken together, it seems that Nfl levels could be potentially used as a prognostic biomarker for an aggressive disease course and secondary progression of the disease.

Additional studies (Gunnarsson et al. 2011; Romme Christensen et al. 2014; Kuhle et al. 2015b) supports the idea that Nfl alone, or in combination with other markers of CNS damage, can be used as a marker of neuronal damage. For instance, treatment with fingolimod, natalizumab, and rituximab have all been shown to decrease CSF Nfl levels. Although measurement of Nfl levels seems to be a good candidate as a biomarker, they have not entered into clinical utility because of the necessity to confirm 
A. Paul et al.

these findings in larger samples with a longitudinal cohort to determine whether Nfl levels prior to treatment are predictive biomarkers or just correlative to clinical response. In addition to $\mathrm{Nfl}$, it has been shown that several other markers of neuronal and glial cell damage can be elevated in MS patients compared to healthy controls. One of them is GFAP (Isaacs et al. 1998). GFAP is an intermediate filament (IF) protein that is mainly expressed by astrocytes (Jacque et al. 1978) but also by ependymal cells (Roessmann et al. 1980). It has been shown that increased levels of GFAP in the CSF of MS patients are associated with astrocyte damage and astrogliosis (Rosengren et al. 1995; Malmestrom et al. 2003; Norgren et al. 2004) and severe disability (Petzold et al. 2002).

\section{Serum Osteopontin (OPN)}

OPN, or early T-lymphocyte activation-1, is a sialoprotein originated by bone and a large number of tissues and cells. OPN has been described as a secreted protein involved in a wide spectrum of physiopathological processes, as OPN expression was demonstrated in the nucleus and cytoplasm of several different cells. OPN takes its origin from the role of this protein in bone metabolism, as it exerts a major function in controlling biomineralization, stimulating adhesion, migration, and bone resorption by osteoclasts (Hunter et al. 1996; Chellaiah et al. 2003; Scatena et al. 2007). Among its non-bone-related functions, OPN plays a pivotal role in the regulation of immune cell functions, including monocyte adhesion, migration, differentiation, and phagocytosis (Crawford et al. 1998; Giachelli et al. 1998; O’Regan et al. 1999; Weber et al. 2002). It also exerts an influence on Th cell polarization to Th1 or Th2 phenotypes by enhancing Th1 and inhibiting Th2 cytokine expression (Ashkar et al. 2000). OPN was also demonstrated to have a role in the development and progression of several autoimmune diseases, such as MS (Comi et al. 2012; Wen et al. 2012; Shimizu et al. 2013; Kivisäkk et al. 2014) rheumatoid arthritis (Iwadate et al. 2014; Ji et al. 2014) psoriasis (Chen et al. 2009), and Graves' disease (Xu et al. 2011). In patients with MS, expression of OPN has been found within the MS lesions (Chabas et al. 2001; Sinclair et al. 2005), and it is significantly higher in blood and CSF from patients compared with healthy controls. Although several studies have shown that OPN correlates to disease severity, relapse rate (Vogt et al. 2003, 2004; Comabella et al. 2005; Wen et al. 2012; Szalardy et al. 2013), and also to disease severity in PPMS (Bornsen et al. 2011), there is no consensus in considering OPN levels as a prognostic biomarker of disease severity because of controversial results from other studies in MS that did not find any association between serum OPN levels and disease severity (Kivisäkk et al. 2014) or relapses (Runia et al. 2014). As such, the association of OPN with the disease may be correlative with disease susceptibility rather than predictive of disease severity.

\section{Myelin-Reactive T Cells}

Infiltration of autoreactive myelin-specific CD4 and CD8 $\mathrm{T}$ cells into the CNS, leading to an increase of proinflammatory cytokines, is a hallmark of MS (Goverman 2009; Hvilsted et al. 2011). In vitro, myelin-specific CD4 T cells could stimulate microglial cells to secrete inflammatory cytokines, including interleukin (IL)-1 $\beta$, IL-4, IL-6, IL-12, and IL-13 (Chabot et al. 2002; Strachan-Whaley et al. 2014). Many studies have described increased circulating myelin-reactive CD4 and CD8 cells in the peripheral blood from MS patients (Ota et al. 1990; Pette et al. 1990; Martin et al. 1991). However, applying this as a diagnostic tool in MS has been hindered by the rarity of myelin-specific $\mathrm{T}$ cells in peripheral blood and nonspecific bystander activation. It has been shown that major histocompatibility complex (MHC) class II tetramers specific for myelin-oligodendrocyte glycoprotein are more frequent in MS patients as compared to healthy controls (Raddassi et al. 2011). One study investigated the cytokine production and RNA profiles of these myelin-reactive $\mathrm{T}$ cells and showed an increase in IFN- $\gamma$, granulocyte macrophage colony-stimulating factor (GM-CSF), and IL-17 production in myelin-reactive CD4 cells from MS patients (Cao et al. 2015). Studies have identified a phenotypic 
and transcriptional signature of myelin-reactive T cells in MS patients. The utility of these cells as the biomarker for disease diagnosis and prognosis is still debatable.

\section{Antibody Reactivity Patterns}

Antigen microarray is a great tool to study the antibody reactivity patterns using a limited amount of sample (Quintana et al. 2012). Quintana and others have reported the use of antigen arrays to characterize immune responses in MS (Kanter et al. 2006; Garren et al. 2008; Quintana et al. 2008). These studies focused to characterize antibody signatures associated with disease stages and pathological subtypes in MS. Antigen arrays are also used to measure lipid antibody responses in CSF from MS patients (Kanter et al. 2006). MS patients showed antibody signatures that were specific to various CNS antigens. The potential pathogenic role of these antibodies and their lipid targets are also evaluated further in an EAE model. Administration of pathogenic antibodies or their target lipids worsens the EAE symptoms (Kanter et al. 2006; Quintana et al. 2008; Farez et al. 2009).

\section{Microbiome-Associated Lipopeptides}

The gut microbiome has been implicated in a number of immunologic disorders, which include MS, inflammatory bowel disease (IBD), type 1 diabetes, and rheumatoid arthritis (RA) (Scher et al. 2013; Kostic et al. 2014; Alkanani et al. 2015). An experimental EAE mouse model for MS showed that altering the gut microbiome modulated CNS autoimmunity. Another relapsing remitting EAE mouse model showed that transgenic SJL/J mice raised in germ-free conditions were protected against developing the disease and introduction of commensal microbiota into the gut restored susceptibility (Berer et al. 2011). Whereas gnotobiotic mice are relatively immunocompromised because of a lack of microbial stimulation promoting immune maturation, specific association of germ-free mice with defined commensal species has been shown to modulate the development and severity of EAE. Studies have shown that certain segmented-fil- amentous bacteria (SFB) drive an expansion of Th17 cell populations and generation of IL-17 in the gut (Ivanov et al. 2009). Monocolonization of the gut of C57BL/6 mice with SFB has been known to promote Th17 accumulation in the spinal cords of mice and induces the development of EAE (Lee et al. 2011). Conversely, the treatment of $\mathrm{C} 57 \mathrm{BL} / 6$ mice with a polysaccharide from the Bacteroides fragilis expands intestinal Foxp $3^{+} \mathrm{CD} 4$ Tregs and protects against the development of CNS autoimmunity (OchoaRepáraz et al. 2010; Round and Mazmanian 2010). When high-throughput $16 \mathrm{~S}$ ribosomal RNA (rRNA) sequencing was performed to investigate the gut microbiome in subjects with MS $(n=61)$ and healthy controls $(n=44)$, alterations in the gut microbiome in MS patients were evident. An increase in the genera Methanobrevibacter and Akkermansia and a decrease in Butyricimonas genera was observed. These alterations in the gut microbiome correlated with variations in the expression of genes involved in dendritic-cell maturation, IFN signaling, and nuclear factor (NF)- $\kappa \mathrm{B}$ signaling pathways in circulating $\mathrm{T}$ cells and monocytes. Patients on disease-modifying treatment (IFN$\beta$ and glatiramer acetate) show greater abundances of the genera Prevotella and Sutterella, and decreased Sarcina, in comparison with untreated patients. MS patients of a second cohort showed elevated breath methane compared to controls, consistent with our observation of increased gut Methanobrevibacter in MS in the first cohort (Jangi et al. 2016). Additional study is required to assess whether the observed alterations in the gut microbiome play a role in, or are a consequence of, MS pathogenesis (Jangi et al. 2016).

A recent study showed that a unique bacterially derived TLR2 ligand called lipid 654 was highly expressed in healthy controls and other neurological diseases (ONDs) when compared to MS samples. It is known that this lipid is produced by a number of bacteroidetes species and not by human cells (Clark et al. 2013; Farrokhi et al. 2013). Although this study used a smaller sample size to draw conclusions about its biological significance in MS, it suggested a possibility that lipids produced by commensal 
A. Paul et al.

organisms may be playing a critical role in MS. Further studies are required to validate these findings and determine their possible utility as biomarkers in MS (Housley et al. 2015).

\section{GENETICS AS BIOMARKERS}

Numerous epidemiological studies have shown that genetic factors have an influence on MS. It has long been shown that polymorphisms of the MHC and human leukocyte antigen (HLA) play an important role in MS risk.

\section{HLA}

The presence of polymorphisms in HLA class II genes of MS patients has supported the idea of a genetic burden for MS. The first studies that focused attention on the presence of genetic predisposition for developing MS showed positive correlations between disease frequency and $\mathrm{DRB1}^{*}$ 1501-DRB5*0101-DQA1*0102, DQB1* 0602 haplotypes. More recent investigations, conducted in many MS cohorts, suggested that the allele mainly responsible for attributing genetic risk in MS population is the HLADRB1*1501 (al-Din et al. 1995; Kwon et al. 1999; Bozikas et al. 2003; Oksenberg et al. 2004; Schmidt et al. 2007). The relevance of this allele lies also in its interaction with vitamin $\mathrm{D}$ that is able to regulate HLA-DRB1* 1501 expression, explaining the already-known link between latitude and risk for MS. In addition, the coexistence of several polymorphisms may lead to the increase of overall risk, via epistatic mechanisms (i.e., DRB1*1501 and DQ1*0102) (Lincoln et al. 2009). Other HLA alleles have been reported to be associated with an increased risk of developing MS, such as DR3 and DR4 haplotypes in the Sardinian population (Marrosu et al. 2004), DRB1*04 in Hutterite families (Dyment et al. 2008), the haplotype $\mathrm{DRB}^{*} 1303$ DQA1*05-DQB1*030 in the non-Ashkenazi Jewish population (Kwon et al. 1999), and

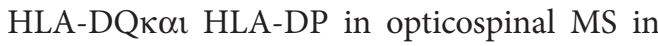
Japanese cohorts (Minohara et al. 2001). All of these reports indicate the disease's genetic complexity. Many studies have tried to investigate whether the presence of a genetic predisposition correlated to clinical parameters or clinical outcomes. Kikuchi et al. (2003) observed that the presence of OCB in the CSF of MS patients was positively correlated with HLA-DRB1* 1501 and negatively correlated with HLA-DRB1*0405 alleles in their Japanese cohort. HLA-DRB1* 15 positively correlated with early onset of MS (Van der Walt et al. 2011), and its correlation with early progression from RRMS to SPMS continues to be controversial (Cournu-Rebeix et al. 2008; Stankovich et al. 2009). Studies showed that the HLA-DRB1*01 allele protects against malignant disease forms (DeLuca et al. 2007). In a study of MS patients, Zivadinov et al. (2007) observed that DRB1*1501-positive patients had worse brain atrophy scores and larger T1 lesions' burden in MRI; similarly, patients positive for $\mathrm{DQB} 1 * 0301$ had worse brain atrophy scores and larger T2 lesions' burden and patients positive for DQB1*0602 had worse gray matter atrophy scores. In another study (Okuda et al. 2009), DRB1*1501-positive patients had lower $\mathrm{N}$-acetyl-aspartate (NAA) levels within normal-appearing white matter (NAWM) combined with larger white matter lesions, worse brain atrophy scores, and impaired cognitive function.

It is also notable that HLA-DRB1*0401, 0408, and 1601 alleles correlate with a greater risk of developing neutralizing antibodies against IFN- $\beta$, resulting in poor therapeutic outcome (Buck et al. 2011).

\section{Non-MHC Polymorphisms Attributing Genetic Risk}

GWAS revealed that many non-MHC single nucleotide polymorphisms have also been associated with greater risk of MS, although most of them only have a modest effect. Among the nonMHC alleles, the polymorphisms of the IL2RA and IL7RA regions seem to be the polymorphisms most commonly associated with MS after MHC (International Multiple Sclerosis Genetics Consortium et al. 2007). However, the list of non-MHC class genes that are associated with MS is increasing and more genes have been found that correlate with increased risk of developing MS (D’Netto et al. 2009; International 
Multiple Sclerosis Genetics Consortium et al. 2011).

\section{CONCLUSIONS}

In conclusion, this article suggests that a lot of effort has been made to identify potential biomarkers for MS. Whereas the identification of an optimal MS biomarker will provide advantages in terms of choosing early treatment options for newly diagnosed patients, the design of personalized treatment for patients, and lower the cost of clinical trials substantially, the heterogeneity of disease in MS makes biomarker identification more challenging. However, a well-characterized and sufficiently powered MS patient population, a reliable measuring platform, and multiple-center validation would overcome some of the challenges in identifying optimal biomarkers for MS. It is possible that for a complex and heterogeneous disease like MS, a single marker is not effective, and thus efforts should be made toward combinatorial analysis of biomarkers to create signatures for MS disease diagnosis, prognosis, and treatment response.

\section{ACKNOWLEDGMENTS}

The authors thank Radhika Raheja, Maria Antonietta Mazzola, Keren Regev, Kristin Vernon, and Murugaiyan Gopal for their comments and suggestions for this review. A.P. had full access to all of the data in the review.

\section{REFERENCES}

Agostini HT, Ryschkewitsch CF, Mory R, Singer EJ, Stoner GL. 1997. JC virus (JCV) genotypes in brain tissue from patients with progressive multifocal leukoencephalopathy (PML) and in urine from controls without PML: Increased frequency of JCV type 2 in PML. J Infect Dis 176: $1-8$.

al-Din AS, el-Khateeb M, Kurdi A, Mubaidin A, Wriekat A, al-Shehab A, Khalil RW. 1995. Multiple sclerosis in Arabs in Jordan. J Neurol Sci 131: 144-149.

Alkanani AK, Hara N, Gottlieb PA, Ir D, Robertson CE, Wagner BD, Frank DN, Zipris D. 2015. Alterations in intestinal microbiota correlate with susceptibility to type 1 diabetes. Diabetes 64: 3510-3520.

Antoniol C, Stankoff B. 2014. Immunological markers for PML prediction in MS patients treated with natalizumab. Front Immunol 5: 668.
Ashkar S, Weber GF, Panoutsakopoulou V, Sanchirico ME, Jansson M, Zawaideh S, Rittling SR, Denhardt DT, Glimcher MJ, Cantor H. 2000. Eta-1 (osteopontin): An early component of type-1 (cell-mediated) immunity. Science 287: 860-864.

Barkhof F. 1999. MRI in multiple sclerosis: Correlation with expanded disability status scale (EDSS). Mult Scler 5: 283-286.

Barkhof F, Calabresi PA, Miller DH, Reingold SC. 2009. Imaging outcomes for neuroprotection and repair in multiple sclerosis trials. Nat Rev Neurol 5: 256-266.

Berer K, Mues M, Koutrolos M, Rasbi ZA, Boziki M, Johner C, Wekerle H, Krishnamoorthy G. 2011. Commensal microbiota and myelin autoantigen cooperate to trigger autoimmune demyelination. Nature 479: 538-541.

Bielekova B, McDermott MP. 2015. Will CSF biomarkers guide future therapeutic decisions in multiple sclerosis? Neurology 84: 1620-1621.

Biomarkers Definitions Working Group. 2001. Biomarkers and surrogate endpoints: Preferred definitions and conceptual framework. Clin Pharmacol Ther 69: 89-95.

Bonneh-Barkay D, Wang G, Starkey A, Hamilton RL, Wiley CA. 2010. In vivo CHI3L1 (YKL-40) expression in astrocytes in acute and chronic neurological diseases. J Neuroinflamm 7: 34.

Bornsen L, Khademi M, Olsson T, Sorensen PS, Sellebjerg F. 2011. Osteopontin concentrations are increased in cerebrospinal fluid during attacks of multiple sclerosis. Mult Scler 17: 32-42.

Bozikas VP, Anagnostouli MC, Petrikis P, Sitzoglou C, Phokas C, Tsakanikas C, Karavatos A. 2003. Familial bipolar disorder and multiple sclerosis: A three-generation HLA family study. Prog Neuropsychopharmacol Biol Psychiatry 27: 835-839.

Brettschneider J, Czerwoniak A, Senel M, Fang L, Kassubek J, Pinkhardt E, Lauda F, Kapfer T, Jesse S, Lehmensiek V, et al. 2010. The chemokine CXCL13 is a prognostic marker in clinically isolated syndrome (CIS). PLoS ONE 5: e11986.

Brew BJ, Davies NW, Cinque P, Clifford DB, Nath A. 2010. Progressive multifocal leukoencephalopathy and other forms of JC virus disease. Nat Rev Neurol 6: 667-679.

Brickshawana A, Hinson SR, Romero MF, Lucchinetti CF, Guo Y, Buttmann M, McKeon A, Pittock SJ, Chang MH, Chen AP, et al. 2014. Investigation of the KIR4.1 potassium channel as a putative antigen in patients with multiple sclerosis: A comparative study. Lancet Neurol 13: 795-806.

Brill L, Goldberg L, Karni A, Petrou P, Abramsky O, Ovadia H, Ben-Hur T, Karussis D, Vaknin-Dembinsky A. 2015. Increased anti-KIR4.1 antibodies in multiple sclerosis: Could it be a marker of disease relapse? Mult Scler 21: 572-579.

Brück W, Bitsch A, Kolenda H, Brück Y, Stiefel M, Lassmann H. 1997. Inflammatory central nervous system demyelination: Correlation of magnetic resonance imaging findings with lesion pathology. Ann Neurol 42: 783-793.

Buck D, Srinivasan R, Oksenberg JR, Goodin DS, Baranzini SE, Beheshtian A, Waubant E, Zamvil SS, Leppert D, Qualley P, et al. 2011. Influence of the HLA-DRB1 genotype on antibody development to interferon $\beta$ in multiple sclerosis. Arch Neurol 68: 480-487. 
A. Paul et al.

Burman J, Raininko R, Blennow K, Zetterberg H, Axelsson M, Malmeström C. 2016. YKL-40 is a CSF biomarker of intrathecal inflammation in secondary progressive multiple sclerosis. J Neuroimmunol 292: 52-57.

Cantó E, Tintoré M, Villar LM, Costa C, Nurtdinov R, Álvarez-Cermeño JC, Arrambide G, Reverter F, Deisenhammer F, Hegen H, et al. 2015. Chitinase 3-like 1: Prognostic biomarker in clinically isolated syndromes. Brain 138: 918-931.

Cao Y, Goods BA, Raddassi K, Nepom GT, Kwok WW, Love JC, Hafler DA. 2015. Functional inflammatory profiles distinguish myelin-reactive $\mathrm{T}$ cells from patients with multiple sclerosis. Sci Transl Med 7: 287ra274.

Chabas D, Barazine SE, Mitchell D, Bernard CC, Rittling SR, Denhardt DT, Sobel RA, Lock C, Karpuj M, Pedotti R, et al. 2001. The influence of the proinflammatory cytokine, osteopontin, on autoimmune demyelinating disease. Science 294: 1731-1735.

Chabot S, Yong FP, Le DM, Metz LM, Myles T, Yong VM. 2002. Cytokine production in T lymphocyte-microglia interaction is attenuated by glatiramer acetate: A mechanism for therapeutic efficacy in multiple sclerosis. Mult Scler 8: 299-306.

Chastre A, Hafler DA, O'Connor KC. 2016. Evaluation of KIR4.1 as an immune target in multiple sclerosis. N Engl J Med 374: 1495-1496.

Chellaiah MA, Kizer N, Biswas R, Alvarez U, StraussSchoenberger J, Rifas L, Rittling SR, Denhardt DT, Hruska KA. 2003. Osteopontin deficiency produces osteoclast dysfunction due to reduced CD44 surface expression. Mol Biol Cell 14: 173-189.

Chen YJ, Shen JL, Wu CY, Chang YT, Chen CM, Lee FY. 2009. Elevated plasma osteopontin level is associated with occurrence of psoriasis and is an unfavorable cardiovascular risk factor in patients with psoriasis. J Am Acad Dermatol 60: 225-230.

Clark RB, Cervantes JL, Maciejewski MW, Farrokhi V, Nemati R, Yao X, Anstadt E, Fujiwara M, Wright KT, Riddle C, et al. 2013. Serine lipids of Porphyromonas gingivalis are human and mouse Toll-like receptor 2 ligands. Infect Immun 81: 3479-3489.

Clowes JA, Hannon RA, Yap TS, Hoyle NR, Blumsohn A, Eastell R. 2002. Effect of feeding on bone turnover markers and its impact on biological variability of measurements. Bone 30: 886-890.

Cohen SR, Herndon RM, McKhann GM. 1976. Radioimmunoassay of myelin basic protein in spinal fluid. An index of active demyelination. N Engl J Med 295: 1455-1457.

Cohen JA, Reingold SC, Polman CH, Wolinsky JS; International Advisory Committee on Clinical Trials in Multiple Sclerosis. 2012. Disability outcome measures in multiple sclerosis clinical trials: Current status and future prospects. Lancet Neurol 11: 467-476.

Comabella M, Martin R. 2007. Genomics in multiple sclerosis-Current state and future directions. J Neuroimmunol 187: 1-8.

Comabella M, Montalban X. 2014. Body fluid biomarkers in multiple sclerosis. Lancet Neurol 13: 113-126.

Comabella M, Pericot I, Goertsches R, Nos C, Castillo M, Blas Navarro J, Río J, Montalban X. 2005. Plasma osteopontin levels in multiple sclerosis. J Neuroimmunol 158: $231-239$.
Comabella M, Fernández M, Martin R, Rivera-Vallvé S, Borrás $\mathrm{E}$, Chiva $\mathrm{C}$, Julià $\mathrm{E}$, Rovira $\mathrm{A}$, Cantó $\mathrm{E}$, Alvarez-Cermeño JC, et al. 2010. Cerebrospinal fluid chitinase 3-like 1 levels are associated with conversion to multiple sclerosis. Brain 133: 1082-1093.

Comi C, Cappellano G, Chiocchetti A, Orilieri E, Buttini S, Ghezzi L, Galimberti D, Guerini F, Barizzone N, Perla F, et al. 2012. The impact of osteopontin gene variations on multiple sclerosis development and progression. Clin Dev Immunol 2012: 212893.

Compston A, Coles A. 2008. Multiple sclerosis. Lancet 372: 1502-1517.

Correale J, Fiol M. 2011. Chitinase effects on immune cell response in neuromyelitis optica and multiple sclerosis. Mult Scler 17: 521-531.

Corvol JC, Pelletier D, Henry RG, Caillier SJ, Wang J, Pappas D, Casazza S, Okuda DT, Hauser SL, Oksenberg JR, et al. 2008. Abrogation of $\mathrm{T}$ cell quiescence characterizes patients at high risk for multiple sclerosis after the initial neurological event. Proc Natl Acad Sci 105: 11839-11844.

Cournu-Rebeix I, Génin E, Leray E, Babron MC, Cohen J, Gout C, Alizadeh M, Perdry H, Semana G, Brassat D, et al. 2008. HLA-DRB1*15 allele influences the later course of relapsing remitting multiple sclerosis. Genes Immun 9: $570-574$

Cox MB, Cairns MJ, Gandhi KS, Carroll AP, Moscovis S, Stewart GJ, Broadley S, Scott RJ, Booth DR, Lechner-Scott J, et al. 2010. MicroRNAs miR-17 and miR-20a inhibit T cell activation genes and are under-expressed in MS whole blood. PLOS ONE 5: e12132.

Crawford HC, Matrisian LM, Liaw L. 1998. Distinct roles of osteopontin in host defense activity and tumor survival during squamous cell carcinoma progression in vivo. Cancer Res 58: 5206-5215.

Crotty S. 2012. The 1-1-1 fallacy. Immunol Rev 247: 133 142.

Cyster JG. 2005. Chemokines, sphingosine-1-phosphate, and cell migration in secondary lymphoid organs. Annu Rev Immunol 23: 127-159.

Dalton CM, Chard DT, Davies GR, Miszkiel KA, Altmann DR, Fernando K, Plant GT, Thompson AJ, Miller DH 2004. Early development of multiple sclerosis is associated with progressive grey matter atrophy in patients presenting with clinically isolated syndromes. Brain 127: 1101-1107.

Davenport RD, Keren DF. 1988. Oligoclonal bands in cerebrospinal fluids: Significance of corresponding bands in serum for diagnosis of multiple sclerosis. Clin Chem 34: 764-765.

Deininger SO, Ebert MP, Fütterer A, Gerhard M, Röcken C. 2008. MALDI imaging combined with hierarchical clustering as a new tool for the interpretation of complex human cancers. J Proteome Res 7: 5230-5236.

DeLuca GC, Ramagopalan SV, Herrera BM, Dyment DA, Lincoln MR, Montpetit A, Pugliatti M, Barnardo MC Risch NJ, Sadovnick AD, et al. 2007. An extremes of outcome strategy provides evidence that multiple sclerosis severity is determined by alleles at the HLA-DRB1 locus. Proc Natl Acad Sci 104: 20896-20901.

De Stefano N, Giorgio A, Battaglini M, Rovaris M, Sormani MP, Barkhof F, Korteweg T, Enzinger C, Fazekas F, Calabrese $\mathrm{M}$, et al. 2010. Assessing brain atrophy rates in a 
large population of untreated multiple sclerosis subtypes Neurology 74: 1868-1876.

Disanto G, Adiutori R, Dobson R, Martinelli V, Dalla Costa G, Runia T, Evdoshenko E, Thouvenot E, Trojano M, Norgren N, et al. 2015. Serum neurofilament light chain levels are increased in patients with a clinically isolated syndrome. J Neurol Neurosurg Psychiatry 87: 126-129.

D’Netto MJ, Ward H, Morrison KM, Ramagopalan SV, Dyment DA, DeLuca GC, Handunnetthi L, Sadovnick AD Ebers GC. 2009. Risk alleles for multiple sclerosis in multiplex families. Neurology 72: 1984-1988.

Du C, Liu C, Kang J, Zhao G, Ye Z, Huang S, Li Z, Wu Z, Pei G. 2009. MicroRNA miR-326 regulates $\mathrm{T}_{\mathrm{H}^{-}} 17$ differentiation and is associated with the pathogenesis of multiple sclerosis. Nat Immunol 10: 1252-1259.

Dyment DA, Cader MZ, Datta A, Broxholme SJ, Cherny SS, Willer CJ, Ramagopalan S, Herrera BM, Orton S, Chao M, et al. 2008. A first stage genome-wide screen for regions shared identical-by-descent in Hutterite families with multiple sclerosis. Am J Med Genet B Neuropsychiatr Genet 147B: 467-472.

Esteller M. 2011. Non-coding RNAs in human disease. Nat Rev Genet 12: 861-874.

Farez MF, Quintana FJ, Gandhi R, Izquierdo G, Lucas M, Weiner HL. 2009. Toll-like receptor 2 and poly(ADPribose) polymerase 1 promote central nervous system neuroinflammation in progressive EAE. Nat Immunol 10: $958-964$

Farrokhi V, Nemati R, Nichols FC, Yao X, Anstadt E, Fujiwara M, Grady J, Wakefield D, Castro D, Donaldson J, et al. 2013. Bacterial lipodipeptide, Lipid 654, is a microbiome-associated biomarker for multiple sclerosis. Clin Transl Immunol 2: e8.

Fenoglio C, Cantoni C, De Riz M, Ridolfi E, Cortini F, Serpente M, Villa C, Comi C, Monaco F, Mellesi L, et al. 2011. Expression and genetic analysis of miRNAs involved in $\mathrm{CD} 4^{+}$cell activation in patients with multiple sclerosis. Neurosci Lett 504: 9-12.

Festa ED, Hankiewicz K, Kim S, Skurnick J, Wolansky LJ, Cook SD, Cadavid D. 2009. Serum levels of CXCL13 are elevated in active multiple sclerosis. Mult Scler 15: 12711279.

Fisher E, Rudick RA, Simon JH, Cutter G, Gaier M, Lee JC, Miller D, Weinstock-Guttman B, Mass MK, Dougherty DS, et al. 2002. Eight-year follow-up study of brain atrophy in patients with MS. Neurology 59: 1412-1420.

Fisher E, Lee JC, Nakamura K, Rudick RA. 2008. Gray matter atrophy in multiple sclerosis: A longitudinal study. Ann Neurol 64: 255-265.

Fisniku LK, Brex PA, Altmann DR, Miszkiel KA, Benton CE, Lanyon R, Thompson AJ, Miller DH. 2008. Disability and T2 MRI lesions: A 20-year follow-up of patients with relapse onset of multiple sclerosis. Brain 131: 808-817.

Franck J, Arafah K, Elayed M, Bonnel D, Vergara D, Jacquet A, Vinatier D, Wisztorski M, Day R, Fournier I, et al. 2009. MALDI imaging mass spectrometry state of the art technology in clinical proteomics. Mol Cell Proteomics 8: 2023-2033.

Gandhi R. 2015. miRNA in multiple sclerosis: Search for novel biomarkers. Mult Scler 21: 1095-1103.
Gandhi R, Healy B, Gholipour T, Egorova S, Musallam A, Hussain MS, Nejad P, Patel B, Hei H, Khoury S, et al. 2013. Circulating microRNAs as biomarkers for disease staging in multiple sclerosis. Ann Neurol 73: 729-740.

Garren H, Robinson WH, Krasulová E, Havrdová E, Nadj C, Selmaj K, Losy J, Nadj I, Radue EW, Kidd BA, et al. 2008. Phase 2 trial of a DNA vaccine encoding myelin basic protein for multiple sclerosis. Ann Neurol 63: 611-620.

Geurts JJ, Calabrese M, Fisher E, Rudick RA. 2012. Measurement and clinical effect of grey matter pathology in multiple sclerosis. Lancet Neurol 11: 1082-1092.

Giachelli CM, Lombardi D, Johnson RJ, Murry CE, Almeida M. 1998. Evidence for a role of osteopontin in macrophage infiltration in response to pathological stimuli in vivo. Am J Pathol 152: 353-358.

Goverman J. 2009. Autoimmune T cell responses in the central nervous system. Nat Rev Immunol 9: 393-407.

Gudewill S, Pollmächer T, Vedder H, Schreiber W, Fassbender K, Holsboer F. 1992. Nocturnal plasma levels of cytokines in healthy men. Eur Arch Psychiatry Clin Neurosci 242: 53-56.

Gunnarsson M, Malmeström C, Axelsson M, Sundström P, Dahle C, Vrethem M, Olsson T, Piehl F, Norgren N, Rosengren L, et al. 2011. Axonal damage in relapsing multiple sclerosis is markedly reduced by natalizumab. Ann Neurol 69: 83-89.

Hanke M, Hoefig K, Merz H, Feller AC, Kausch I, Jocham D, Warnecke JM, Sczakiel G. 2010. A robust methodology to study urine microRNA as tumor marker: MicroRNA-126 and microRNA-182 are related to urinary bladder cancer. Urol Oncol 28: 655-661.

Housley WJ, Pitt D, Hafler DA. 2015. Biomarkers in multiple sclerosis. Clin Immunol 161: 51-58.

Hunter GK, Hauschka PV, Poole AR, Rosenberg LC, Goldberg HA. 1996. Nucleation and inhibition of hydroxyapatite formation by mineralized tissue proteins. Biochem J 317: 59-64.

Hvilsted Nielsen H, Toft-Hansen H, Lambertsen KL, Owens T, Finsen B. 2011. Stimulation of adult oligodendrogenesis by myelin-specific T cells. Am J Pathol 179: 20282041.

International Multiple Sclerosis Genetics Consortium; Hafler DA, Compston A, Sawcer S, Lander ES, Daly MJ, De Jager PL, de Bakker PI, Gabriel SB, et al. 2007. Risk alleles for multiple sclerosis identified by a genomewide study. $N$ Engl J Med 357: 851-862.

International Multiple Sclerosis Genetics Consortium; Wellcome Trust Case Control Consortium 2; Sawcer S, Hellenthal G, Pirinen M, Spencer CC, Patsopoulos NA, Moutsianas L, Dilthey A, Su Z, et al. 2011. Genetic risk and a primary role for cell-mediated immune mechanisms in multiple sclerosis. Nature 476: 214-219.

Isaacs A, Baker M, Wavrant-De Vrieze F, Hutton M. 1998. Determination of the gene structure of human GFAP and absence of coding region mutations associated with frontotemporal dementia with parkinsonism linked to chromosome 17. Genomics 51: 152-154.

Ivanov II, Atarashi K, Manel N, Brodie EL, Shima T, Karaoz U, Wei D, Goldfarb KC, Santee CA, Lynch SV, et al. 2009. Induction of intestinal Th17 cells by segmented filamentous bacteria. Cell 139: 485-498. 
A. Paul et al.

Iwadate H, Kobayashi H, Kanno T, Asano T, Saito R, Sato S Suzuki E, Watanabe H, Ohira H. 2014. Plasma osteopontin is correlated with bone resorption markers in rheumatoid arthritis patients. Int J Rheum Dis 17: 50-56.

Jacque CM, Vinner C, Kujas M, Raoul M, Racadot J, Baumann NA. 1978. Determination of glial fibrillary acidic protein (GFAP) in human brain tumors. J Neurol Sci 35: $147-155$.

Jangi S, Gandhi R, Cox LM, Li N, von Glehn F, Yan R, Patel B, Mazzola MA, Liu S, Glanz BL, et al. 2016. Alterations of the human gut microbiome in multiple sclerosis. Nat Commun 7: 12015

Ji HI, Lee SH, Song R, Yang HI, Lee YA, Hong SJ, Kim S, Park YB, Lee SK, Yoo MC, et al. 2014. Serum level of osteopontin as an inflammatory marker does not indicate disease activity or responsiveness to therapeutic treatments in patients with rheumatoid arthritis. Clin Rheumatol 33: 397-402.

Junker A, Krumbholz M, Eisele S, Mohan H, Augstein F Bittner R, Lassmann H, Wekerle H, Hohlfeld R, Mein E. 2009. MicroRNA profiling of multiple sclerosis lesions identifies modulators of the regulatory protein CD47. Brain 132: 3342-3352

Kacperska MJ, Jastrzebski K, Tomasik B, Walenczak J, Konarska-Krol M, Glabinski A. 2015. Selected extracellular microRNA as potential biomarkers of multiple sclerosis activity-Preliminary study. J Mol Neurosci 56: 154-163.

Kanter JL, Narayana S, Ho PP, Catz I, Warren KG, Sobel RA, Steinman L, Robinson WH. 2006. Functional inflammatory profiles distinguish myelin-reactive $\mathrm{T}$ cells from patients with multiple sclerosis. Nat Med 12: 138-143.

Katz D, Taubenberger JK, Cannella B, McFarlin DE, Raine CS, McFarland HF. 1993. Correlation between magnetic resonance imaging findings and lesion development in chronic, active multiple sclerosis. Ann Neurol 34: 661669.

Keller A, Leidinger P, Lange J, Borries A, Schroers H, Scheffler M, Lenhof HP, Ruprecht K, Meese E. 2009. Multiple sclerosis: MicroRNA expression profiles accurately differentiate patients with relapsing-remitting disease from healthy controls. PLoS ONE 4: e7440.

Khademi M, Kockum I, Andersson ML, Iacobaeus E, Brundin L, Sellebjerg F, Hillert J, Piehl F, Olsson T. 2011. Cerebrospinal fluid CXCL13 in multiple sclerosis: A suggestive prognostic marker for the disease course. Mult Scler 17: 335-343.

Khoury SJ, Guttmann CR, Orav EJ, Hohol MJ, Ahn SS, Hsu L, Kikinis R, Mackin GA, Jolesz FA, Weiner HL. 1994 Longitudinal MRI in multiple sclerosis: Correlation between disability and lesion burden. Neurology 44: 2120 2124

Kikuchi S, Fukazawa T, Niino M, Yabe I, Miyagishi R, Hamada T, Hashimoto SA, Tashiro K. 2003. HLA-related subpopulations of MS in Japanese with and without oligoclonal IgG bands. Human leukocyte antigen. Neurology 60: $647-651$

Kivisäkk P, Healy BC, Francois K, Gandhi R, Gholipour T, Egorova S, Sevdalinova V, Quintana F, Chitnis T, Weiner HL, et al. 2014. Evaluation of circulating osteopontin levels in an unselected cohort of patients with multiple sclerosis: Relevance for biomarker development. Mult Scler 20: $438-444$
Kostic AD, Xavier RJ, Gevers D. 2014. The microbiome in inflammatory bowel disease: Current status and the future ahead. Gastroenterology 146: 1489-1499.

Kuhle J, Malmeström C, Axelsson M, Plattner K, Yaldizli O, Derfuss T, Giovannoni G, Kappos L, Lycke J. 2013. Neurofilament light and heavy subunits compared as therapeutic biomarkers in multiple sclerosis. Acta Neurol Scand 128: e33-e36.

Kuhle J, Disanto G, Dobson R, Adiutori R, Bianchi L, Topping J, Bestwick JP, Meier UC, Marta M, Dalla Costa G, et al. 2015a. Conversion from clinically isolated syndrome to multiple sclerosis: A large multicentre study. Mult Scler 21: 1013-1024.

Kuhle J, Disanto G, Lorscheider J, Stites T, Chen Y, Dahlke F, Francis G, Shrinivasan A, Radue EW, Giovannoni G, et al. 2015b. Fingolimod and CSF neurofilament light chain levels in relapsing-remitting multiple sclerosis. Neurology 84: 1639-1643.

Kwon OJ, Karni A, Israel S, Brautbar C, Amar A, Meiner Z, Abramsky O, Karussis D. 1999. HLA class II susceptibility to multiple sclerosis among Ashkenazi and non-Ashkenazi Jews. Arch Neurol 56: 555-560.

Lassmann H, Bruck W, Lucchinetti CF. 2007. The immunopathology of multiple sclerosis: An overview. Brain Pathol 17: 210-218.

Lee YK, Menezes JS, Umesaki Y, Mazmanian SK. 2011. Proinflammatory T-cell responses to gut microbiota promote experimental autoimmune encephalomyelitis. Proc Natl Acad Sci 108: 4615-4622.

Lennon VA, Kryzer TJ, Pittock SJ, Verkman AS, Hinson SR. 2005. IgG marker of optic-spinal multiple sclerosis binds to the aquaporin-4 water channel. J Exp Med 202: $473-$ 477.

Lewis BP, Shih IH, Jones-Rhoades MW, Bartel DP, Burge CB. 2003. Prediction of mammalian microRNA targets. Cell 115: 787-798.

Li DK, Held U, Petkau J, Daumer M, Barkhof F, Fazekas F, Frank JA, Kappos L, Miller DH, Simon JH, et al. 2006. MRI T2 lesion burden in multiple sclerosis: A plateauing relationship with clinical disability. Neurology 66: 13841389.

Lincoln MR, Ramagopalan SV, Chao MJ, Herrera BM, Deluca GC, Orton SM, Dyment DA, Sadovnick AD, Ebers GC. 2009. Epistasis among HLA-DRB1, HLA-DQA1, and HLA-DQB1 loci determines multiple sclerosis susceptibility. Proc Natl Acad Sci 106: 7542-7547.

Lindberg RL, Hoffmann F, Mehling M, Kuhle J, Kappos L. 2010. Altered expression of miR-17-5p in CD4 $4^{+}$lymphocytes of relapsing-remitting multiple sclerosis patients. Eur J Immunol 40: 888-898.

Littman DR, Rudensky AY. 2010. Th17 and regulatory T cells in mediating and restraining inflammation. Cell 140: $845-858$.

Liu A, Pollard K. 2015. Biobanking in the 21st century (pp. 55-68). New York: Springer.

Lund SA, Giachelli CM, Scatena M. 2009. The role of osteopontin in inflammatory processes. J Cell Commun Signal 3: $311-322$.

Malmestrom C, Haghighi S, Rosengren L, Andersen O, Lycke J. 2003. Neurofilament light protein and glial fibril- 
lary acidic protein as biological markers in MS. Neurology 61: 1720-1725.

Marrosu MG, Sardu C, Cocco E, Costa G, Murru MR, Mancosu C, Murru R, Lai M, Contu P. 2004. Bias in parental transmission of the HLA-DR3 allele in Sardinian multiple sclerosis. Neurology 63: 1084-1086.

Martin R, Howell MD, Jaraquemada D, Flerlage M, Richert J, Brostoff S, Long EO, McFarlin DE, McFarland HF. 1991. A myelin basic protein peptide is recognized by cytotoxic $\mathrm{T}$ cells in the context of four HLA-DR types associated with multiple sclerosis. J Exp Med 173: 19-24.

Martinelli-Boneschi F, Fenoglio C, Brambilla P, Sorosina M, Giacalone G, Esposito F, Serpente M, Cantoni C, Ridolfi E, Rodegher M, et al. 2012. MicroRNA and mRNA expression profile screening in multiple sclerosis patients to unravel novel pathogenic steps and identify potential biomarkers. Neurosci Lett 508: 4-8.

Martínez MA, Olsson B, Bau L, Matas E, Cobo Calvo Á, Andreasson U, Blennow K, Romero-Pinel L, MartínezYélamos S, Zetterberg H. 2015. Glial and neuronal markers in cerebrospinal fluid predict progression in multiple sclerosis. Mult Scler 21: 550-561.

Mellick GD, Silburn PA, Sutherland GT, Siebert GA. 2010 Exploiting the potential of molecular profiling in Parkinson's disease: Current practice and future probabilities. Expert Rev Mol Diagn 10: 1035-1050.

Miller D, Barkhof F, Montalban X, Thompson A, Filippi M 2005. Clinically isolated syndromes suggestive of multiple sclerosis. Part I: Natural history, pathogenesis, diagnosis, and prognosis. Lancet Neurol 4: 281-288.

Miller D, Weinshenker BG, Filippi M, Banwell BL, Cohen JA, Freedman MS, Galetta SL, Hutchinson M, Johnson RT, Kappos L, et al. 2008. Differential diagnosis of suspected multiple sclerosis: A consensus approach. Mult Scler 14: 1157-1174.

Minohara M, Ochi H, Matsushita S, Irie A, Nishimura Y, Kira J. 2001. Differences between T-cell reactivities to major myelin protein-derived peptides in opticospinal and conventional forms of multiple sclerosis and healthy controls. Tissue Antigens 57: 447-456.

Mitchell PS, Parkin RK, Kroh EM, Fritz BR, Wyman SK, Pogosova-Agadjanyan EL, Peterson A, Noteboom J, O'Briant KC, Allen A, et al. 2008. Circulating microRNAs as stable blood-based markers for cancer detection. Proc Natl Acad Sci 105: 10513-10518.

Modvig S, Degn M, Horwitz H, Cramer SP, Larsson HB, Wanscher B, Sellebjerg F, Frederiksen JL. 2013. Relationship between cerebrospinal fluid biomarkers for inflammation, demyelination and neurodegeneration in acute optic neuritis. PLoS ONE 8: e77163.

Modvig S, Degn M, Roed H, Sørensen TL, Larsson HB, Langkilde AR, Frederiksen JL, Sellebjerg F. 2015. Cerebrospinal fluid levels of chitinase 3-like 1 and neurofilament light chain predict multiple sclerosis development and disability after optic neuritis. Mult Scler 21: 17611770.

Nerrant E, Salsac C, Charif M, Ayrignac X, Carra-Dalliere C, Castelnovo G, Goulabchand R, Tisseyre J, Raoul C, Eliaou JF, et al. 2014. Lack of confirmation of anti-inward rectifying potassium channel 4.1 antibodies as reliable markers of multiple sclerosis. Mult Scler 20: 1699-1703.
Nielsen JM, Korteweg T, Barkhof F, Uitdehaag BM, Polman CH. 2005. Overdiagnosis of multiple sclerosis and magnetic resonance imaging criteria. Ann Neurol 58: 781783.

Nikula T, Mykkanen J, Simell O, Lahesmaa R. 2013. Genome-wide comparison of two RNA-stabilizing reagents for transcriptional profiling of peripheral blood. Transl Res 161: 181-188.

Norgren N, Sundström P, Svenningsson A, Rosengren L, Stigbrand T, Gunnarsson M. 2004. Neurofilament and glial fibrillary acidic protein in multiple sclerosis. Neurology 63: 1586-1590.

Nylander A, Hafler DA. 2012. Multiple sclerosis. J Clin Invest 122: $1180-1188$.

Ochoa-Repáraz J, Mielcarz DW, Wang Y, Begum-Haque S, Dasgupta S, Kasper DL, Kasper LH. 2010. A polysaccharide from the human commensal Bacteroides fragilis protects against CNS demyelinating disease. Mucosal Immunol 3: 487-495.

Okada T, Cyster JG. 2006. B cell migration and interactions in the early phase of antibody responses. Curr Opin Immunol 18: 278-285.

Oksenberg JR, Barcellos LF, Cree BA, Baranzini SE, Bugawan TL, Khan O, Lincoln RR, Swerdlin A, Mignot E, Lin L, et al. 2004. Mapping multiple sclerosis susceptibility to the HLA-DR locus in African Americans. Am J Hum Genet 74: $160-167$

Okuda DT, Srinivasan R, Oksenberg JR, Goodin DS, Baranzini SE, Beheshtian A, Waubant E, Zamvil SS, Leppert D, Qualley P, et al. 2009. Genotype-phenotype correlations in multiple sclerosis: HLA genes influence disease severity inferred by 1HMR spectroscopy and MRI measures. Brain 132: 250-259.

Olsson T, Achiron A, Alfredsson L, Berger T, Brassat D, Chan A, Comi G, Eraksoy M, Hegen H, Hillert J, et al. 2013. Anti-JC virus antibody prevalence in a multinational multiple sclerosis cohort. Mult Scler 19: 1533-1538.

O’Regan AW, Chupp GL, Lowry JA, Goetschkes M, Mulligan N, Berman JS. 1999. Osteopontin is associated with T cells in sarcoid granulomas and has $\mathrm{T}$ cell adhesive and cytokine-like properties in vitro. J Immunol 162: 10241031.

Ota K, Matsui M, Milford EL, Mackin GA, Weiner HL, Hafler DA. 1990. T-cell recognition of an immunodominant myelin basic protein epitope in multiple sclerosis. Nature 346: 183-187.

Otaegui D, Baranzini SE, Armañanzas R, Calvo B, MuñozCulla M, Khankhanian P, Inza I, Lozano JA, CastilloTriviño T, Asensio A, et al. 2009. Differential micro RNA expression in PBMC from multiple sclerosis patients. PLoS ONE 4: e6309.

Outteryck O, Zéphir H, Salleron J, Ongagna JC, Etxeberria A, Collongues N, Lacour A, Fleury MC, Blanc F, Giroux $\mathrm{M}$, et al. 2014. JC-virus seroconversion in multiple sclerosis patients receiving natalizumab. Mult Scler 20: 822 829.

Padgett BL, Walker DL. 1973. Prevalence of antibodies in human sera against JC virus, an isolate from a case of progressive multifocal leukoencephalopathy. J Infect Dis 127: 467-470.

Park NJ, Zhou H, Elashoff D, Henson BS, Kastratovic DA, Abemayor E, Wong DT. 2009. Salivary microRNA: Dis- 
A. Paul et al.

covery, characterization, and clinical utility for oral cancer detection. Clin Cancer Res 15: 5473-5477.

Peltomaa R, Paimela L, Harvey S, Helve T, Leirisalo-Repo M. 2001. Increased level of YKL-40 in sera from patients with early rheumatoid arthritis: A new marker for disease activity. Rheumatol Int 20: 192-196.

Pette M, Fujita K, Kitze B, Whitaker JN, Albert E, Kappos L, Wekerle H. 1990. Myelin basic protein-specific T lymphocyte lines from MS patients and healthy individuals. Neurology 40: 1770-1776.

Petzold A, Eikelenboom MJ, Gveric D, Keir G, Chapman M, Lazeron RH, Cuzner ML, Polman CH, Uitdehaag BM, Thompson EJ, et al. 2002. Markers for different glial cell responses in multiple sclerosis: Clinical and pathological correlations. Brain 125: 1462-1473.

Plavina T, Subramanyam M, Bloomgren G, Richman S, Pace A, Lee S, Schlain B, Campagnolo D, Belachew S, Ticho B. 2014. Anti-JC virus antibody levels in serum or plasma further define risk of natalizumab-associated progressive multifocal leukoencephalopathy. Ann Neurol 76: $802-$ 812.

Plebani M. 2006. Errors in clinical laboratories or errors in laboratory medicine? Clin Chem Lab Med 44: 750-759.

Polman CH, O'Connor PW, Havrdova E, Hutchinson M, Kappos L, Miller DH, Phillips JT, Lublin FD, Giovannoni G, Wajgt A, et al. 2006. A randomized, placebo-controlled trial of natalizumab for relapsing multiple sclerosis. $N$ Engl J Med 354: 899-910.

Polman CH, Bertolotto A, Deisenhammer F, Giovannoni G, Hartung HP, Hemmer B, Killestein J, McFarland HF, Oger J, Pachner AR, et al. 2010. Recommendations for clinical use of data on neutralising antibodies to interferon- $\beta$ therapy in multiple sclerosis. Lancet Neurol 9: 740750 .

Poser CM, Paty DW, Scheinberg L, McDonald WI, Davis FA, Ebers GC, Johnson KP, Sibley WA, Silbergerg DH, Tourtellotte WW. 1983. New diagnostic criteria for multiple sclerosis: Guidelines for research protocols. Ann Neurol 13: $227-231$

Pröbstel AK, Kuhle J, Lecourt AC, Vock I, Sanderson NS, Kappos L, Derfuss T. 2016. Multiple sclerosis and antibodies against KIR4.1. N Engl J Med 374: 1496-1498.

Prosperini L, Gallo V, Petsas N, Borriello G, Pozzilli C. 2009. One-year MRI scan predicts clinical response to interferon $\beta$ in multiple sclerosis. Eur J Neurol 16: 1202-1209.

Qu Z, Li W, Fu B. 2014. MicroRNAs in autoimmune diseases. Biomed Res Int 2014: 527895.

Quintana FJ, Farez MF, Viglietta V, Iglesias AH, Merbl Y, Izquierdo G, Lucas M, Basso AS, Khoury SJ, Lucchinetti CF, et al. 2008. Antigen microarrays identify unique serum autoantibody signatures in clinical and pathologic subtypes of multiple sclerosis. Proc Natl Acad Sci 105: 18889-18894.

Quintana FJ, Yeste A, Weiner HL, Covacu R. 2012. Lipids and lipid-reactive antibodies as biomarkers for multiple sclerosis. J Neuroimmunol 248: 53-57.

Rababah M, Worthmann H, Deb M, Tryc AB, Ma YT, El Bendary OM, Hecker H, Goldbecker A, Heeren M, Brand $\mathrm{K}$, et al. 2012. Anticoagulants affect matrix metalloproteinase 9 levels in blood samples of stroke patients and healthy controls. Clin Biochem 45: 483-489.
Raddassi K, Kent SC, Yang J, Bourcier K, Bradshaw EM, Seyfert-Margolis V, Nepom GT, Kwok WW, Hafler DA. 2011. Increased frequencies of myelin oligodendrocyte glycoprotein/MHC class II-binding CD4 cells in patients with multiple sclerosis. J Immunol 187: 1039-1046.

Ram M, Sherer Y, Shoenfeld Y. 2006. Matrix metalloproteinase-9 and autoimmune diseases. J Clin Immunol 26: 299-307.

Rashid W, Davies GR, Chard DT, Griffin CM, Altmann DR, Gordon R, Thompson AJ, Miller DH. 2006. Increasing cord atrophy in early relapsing-remitting multiple sclerosis: A 3 year study. J Neurol Neurosurg Psychiatry 77: 5155.

Redell JB, Moore AN, Ward NH III, Hergenroeder GW, Dash PK. 2010. Human traumatic brain injury alters plasma microRNA levels. J Neurotrauma 27: 2147-2156.

Regev K, Paul A, Healy B, von Glenn F, Diaz-Cruz C, Gholipour T, Mazzola MA, Raheja R, Nejad P, Glanz BI, et al. 2016. Comprehensive evaluation of serum microRNAs as biomarkers in multiple sclerosis. Neurol Neuroimmunol Neuroinflamm 3: e267.

Rio J, Castilló J, Rovira A, Tintoré M, Sastre-Garriga J, Horga A, Nos C, Comabella M, Aymerich X, Montalbán X. 2009. Measures in the first year of therapy predict the response to interferon $\beta$ in MS. Mult Scler 15: 848-853.

Rocca MA, Amato MP, De Stefano N, Enzinger C, Geurts JJ, Penner IK, Rovira A, Sumowski JF, Valsasina P, Filippi M, et al. 2015. Clinical and imaging assessment of cognitive dysfunction in multiple sclerosis. Lancet Neurol 14: 302317.

Roessmann U, Velasco ME, Sindely SD, Gambetti P. 1980. Glial fibrillary acidic protein (GFAP) in ependymal cells during development. An immunocytochemical study. Brain Res 200: 13-21.

Rojas RJ, Patrucco L, Edgardo C. 2010. Oligoclonal bands and MRI in clinically isolated syndromes: Predicting conversion time to multiple sclerosis. J Neurol 257: 11881191.

Romme Christensen J, Ratzer R, Börnsen L, Lyksborg M, Garde E, Dyrby TB, Siebner HR, Sorensen PS, Sellebjerg F. 2014. Natalizumab in progressive MS: Results of an open-label, phase 2A, proof-of-concept trial. Neurology 82: 1499-1507.

Rosengren LE, Lycke J, Andersen O. 1995. Glial fibrillary acidic protein in CSF of multiple sclerosis patients: Relation to neurological deficit. J Neurol Sci 133: 61-65.

Round JL, Mazmanian SK. 2010. Inducible Foxp $3^{+}$regulatory T-cell development by a commensal bacterium of the intestinal microbiota. Proc Natl Acad Sci 107: $12204-$ 12209.

Rudick RA, Lee JC, Simon J, Ransohoff RM, Fisher E. 2004 Defining interferon $\beta$ response status in multiple sclerosis patients. Ann Neurol 56: 548-555.

Runia TF, van Meurs M, Nasserinejad K, Hintzen RQ. 2014. No evidence for an association of osteopontin plasma levels with disease activity in multiple sclerosis. Mult Scler 20: $1670-1671$.

Salzer J, Svenningsson A, Sundstrom P. 2010. Neurofilament light as a prognostic marker in multiple sclerosis. Mult Scler 16: 287-292. 
Sawcer S. 2008. The complex genetics of multiple sclerosis: Pitfalls and prospects. Brain 131: 3118-3131.

Scatena M, Liaw L, Giachelli CM. 2007. Osteopontin: A multifunctional molecule regulating chronic inflammation and vascular disease. Arterioscler Thromb Vasc Biol 27: 2302-2309.

Scher JU, Sczesnak A, Longman RS, Segata N, Ubeda C, Bielski C, Rostron T, Cerundolo V, Pamer EG, Abramson SB, et al. 2013. Expansion of intestinal Prevotella copri correlates with enhanced susceptibility to arthritis. eLife 2: $\mathrm{e} 01202$.

Schmidt H, Williamson D, Ashley-Koch A. 2007. HLADR15 haplotype and multiple sclerosis: A HuGE review. Am J Epidemiol 165: 1097-1109.

Shackelton LA, Rambaut A, Pybus OG, Holmes EC. 2006. JC virus evolution and its association with human populations. J Virol 80: 9928-9933.

Shaw CE, Dunbar PR, Macaulay HA, Neale TJ. 1995. Measurement of immune markers in the serum and cerebrospinal fluid of multiple sclerosis patients during clinical remission. J Neurol 242: 53-58.

Shi M, Caudle WM, Zhang J. 2009. Biomarker discovery in neurodegenerative diseases: A proteomic approach. $\mathrm{Neu}$ robiol Dis 35: 157-164.

Shimizu Y, Ota K, Ikeguchi R, Kubo S, Kabasawa C, Uchiyama S. 2013. Plasma osteopontin levels are associated with disease activity in the patients with multiple sclerosis and neuromyelitis optica. J Neuroimmunol 263: 148-151.

Sinclair C, Mirakhur M, Kirk J, Farrell M, McQuaid S. 2005. Up-regulation of osteopontin and $\alpha \beta$-crystallin in the normal-appearing white matter of multiple sclerosis: An immunohistochemical study utilizing tissue microarrays. Neuropathol Appl Neurobiol 31: 292-303.

Smith ME, Stone LA, Albert PS, Frank JA, Martin R, Armstrong M, Maloni H, McFarlin DE, McFarland HF. 1993. Clinical worsening in multiple sclerosis is associated with increased frequency and area of gadopentetate dimeglumine-enhancing magnetic resonance imaging lesions. Ann Neurol 33: 480-489.

Srivastava R, Aslam M, Kalluri SR, Schirmer L, Buck D, Tackenberg B, Rothhammer V, Chan A, Gold R, Berthele A, et al. 2012. Potassium channel KIR4.1 as an immune target in multiple sclerosis. N Engl J Med 367: 115-123.

Stangel M, Fredrikson S, Meinl E, Petzold A, Stüve O, Tumani H. 2013. The utility of cerebrospinal fluid analysis in patients with multiple sclerosis. Nat Rev Neurol 9: 267276.

Stankovich J, Butzkueven H, Marriott M, Chapman C, Tubridy N, Tait BD, Varney MD, Taylor BV, Foote SJ; ANZgene Consortium, et al. 2009. HLA-DRB1 associations with disease susceptibility and clinical course in Australians with multiple sclerosis. Tissue Antigens 74: 17-21.

Stilund M, Gjelstrup MC, Petersen T, Møller HJ, Rasmussen PV, Christensen T. 2015. Biomarkers of inflammation and axonal degeneration/damage in patients with newly diagnosed multiple sclerosis: Contributions of the soluble CD163 CSF/serum ratio to a biomarker panel. PLoS ONE 10: e0119681.

Strachan-Whaley M, Rivest S, Yong VW. 2014. Interactions between microglia and $\mathrm{T}$ cells in multiple sclerosis pathobiology. J Interferon Cytokine Res 34: 615-622.
Sundström P, Juto P, Wadell G, Hallmans G, Svenningsson A, Nyström L, Dillner J, Forsgren L. 2004. An altered immune response to Epstein-Barr virus in multiple sclerosis: A prospective study. Neurology 62: 2277-2282.

Szalardy L, Zador D, Simu M, Bencsik K, Vecsei L, Klivenyi P. 2013. Evaluating biomarkers of neuronal degeneration and neuroinflammation in CSF of patients with multiple sclerosis-osteopontin as a potential marker of clinical severity. J Neurol Sci 331: 38-42.

Teunissen CE, Koel-Simmelink MJ, Pham TV, Knol JC, Khalil M, Trentini A, Killestein J, Nielsen J, Vrenken H, Popescu V, et al. 2011. Identification of biomarkers for diagnosis and progression of MS by MALDI-TOF mass spectrometry. Mult Scler 17: 838-850.

Teunissen C, Menge T, Altintas A, Álvarez-Cermeño JC, Bertolotto A, Berven FS, Brundin L, Comabella M, Degn M, Deisenhammer F, et al. 2013. Consensus definitions and application guidelines for control groups in cerebrospinal fluid biomarker studies in multiple sclerosis. Mult Scler 19: 1802-1809.

Teunissen CE, Malekzadeh A, Leurs C, Bridel C, Killestein J. 2015. Body fluid biomarkers for multiple sclerosis-The long road to clinical application. Nat Rev Neurol 11: 585596.

Tumani H, Hartung HP, Hemmer B, Teunissen C, Deisenhammer F, Giovannoni G, Zettl UK; BioMS Study Group. 2009. Cerebrospinal fluid biomarkers in multiple sclerosis. Neurobiol Dis 35: 117-127.

Van der Walt A, Stankovich J, Bahlo M, Taylor BV, Van der Mei IA, Foote SJ, Rubio JP, Kilpatrick TJ, Butzkueven H. 2011. Heterogeneity at the HLA-DRB1 allelic variation locus does not influence multiple sclerosis disease severity, brain atrophy or cognition. Mult Scler 17: 344-352.

Victora GD, Nussenzweig MC. 2012. Germinal centers. Annu Rev Immunol 30: 429-457.

Vind I, Johansen JS, Price PA, Munkholm P. 2003. Serum YKL-40, a potential new marker of disease activity in patients with inflammatory bowel disease. Scand J Gastroenterol 38: 599-605.

Vogt MH, Lopatinskaya L, Smits M, Polman CH, Nagelkerken L. 2003. Elevated osteopontin levels in active relapsing-remitting multiple sclerosis. Ann Neurol 53: 819822.

Vogt MH, Floris S, Killestein J, Knol DL, Smits M, Barkhof F, Polman CH, Nagelkerken L. 2004. Osteopontin levels and increased disease activity in relapsing-remitting multiple sclerosis patients. J Neuroimmunol 155: 155-160.

Vos K, Steenbakkers P, Miltenburg AM, Bos E, van Den Heuvel MW, van Hogezand RA, de Vries RR, Breedveld FC, Boots AM. 2000. Raised human cartilage glycoprotein-39 plasma levels in patients with rheumatoid arthritis and other inflammatory conditions. Ann Rheum Dis 59: 544-548.

Weber GF, Zawaideh S, Hikita S, Kumar VA, Cantor H, Ashkar S. 2002. Phosphorylation-dependent interaction of osteopontin with its receptors regulates macrophage migration and activation. J Leukoc Biol 72: 752-761.

Weiner HL. 2004. Multiple sclerosis is an inflammatory Tcell-mediated autoimmune disease. Arch Neurol 61: 1613-1615.

Wen SR, Liu GJ, Feng RN, Gong FC, Zhong H, Duan SR, Bi S. 2012. Increased levels of IL-23 and osteopontin in se- 
A. Paul et al.

rum and cerebrospinal fluid of multiple sclerosis patients. J Neuroimmunol 244: 94-96.

Whitaker JN. 1977. Myelin encephalitogenic protein fragments in cerebrospinal fluid of persons with multiple sclerosis. Neurology 27: 911-920.

Whitaker JN, Lisak RP, Bashir RM, Fitch OH, Seyer JM, Krance R, Lawrence JA, Ch'ien LT, O'Sullivan P. 1980. Immunoreactive myelin basic protein in the cerebrospinal fluid in neurological disorders. Ann Neurol 7: 58-64.

Whitaker JN, Williams PH, Layton BA, McFarland HF, Stone LA, Smith ME, Kachelhofer RD, Bradley EL, Burgard S, Zhao G, et al. 1994. Correlation of clinical features and findings on cranial magnetic resonance imaging with urinary myelin basic protein-like material in patients with multiple sclerosis. Annal Neurol 35: 577-585.

World Health Organization. 1993. Biomarkers and risk assessment: Concepts and principles. Geneva, Switzerland: World Health Organization.

Xu L, Ma X, Wang Y, Li X, Qi Y, Cui B, Li X, Ning G, Wang S. 2011. The expression and pathophysiological role of osteopontin in Graves' disease. J Clin Endocrinol Metab 96: E1866-E1870.

Zahednasab H, Balood M. 2014. The role of miR-326 and miR-26a in MS disease activity. Gene 548: 158.

Zhang HL, Wu J, Zhu J. 2010. The immune-modulatory role of apolipoprotein E with emphasis on multiple sclerosis and experimental autoimmune encephalomyelitis. Clin Dev Immunol 2010: 186813.

Zhang J, Cheng Y, Cui W, Li M, Li B, Guo L. 2014. MicroRNA-155 modulates Th1 and Th17 cell differentiation and is associated with multiple sclerosis and experimental autoimmune encephalomyelitis. J Neuroimmunol 266: 56-63.

Zhu S, Pan W, Qian Y. 2013. MicroRNA in immunity and autoimmunity. J Mol Med (Berl) 91: 1039-1050.

Ziemann U, Wahl M, Hattingen E, Tumani H. 2011. Development of biomarkers for multiple sclerosis as a neurodegenerative disorder. Prog Neurobiol 95: 670-685.

Zivadinov R, Leist TP. 2005. Clinical-magnetic resonance imaging correlations in multiple sclerosis. J Neuroimaging 15: 10S-21S.

Zivadinov R, Uxa L, Bratina A, Bosco A, Srinivasaraghavan B, Minagar A, Ukmar M, Benedetto Sy, Zorzon M. 2007 HLA-DRB1*1501, -DQB1*0301, -DQB1*0302, -DQB1* 0602 , and $-\mathrm{DQB1}{ }^{*} 0603$ alleles are associated with more severe disease outcome on MRI in patients with multiple sclerosis. Int Rev Neurobiol 79: 521-535.

Zotos D, Coquet JM, Zhang Y, Light A, D'Costa K, Kallies A, Corcoran LM, Godfrey DI, Toellner KM, Smyth MJ, et al. 2010. IL-21 regulates germinal center B cell differentiation and proliferation through a B cell-intrinsic mechanism. J Exp Med 207: 365-378. 


\section{$\&_{\mathrm{CSH}}^{\infty} \&$ Cold Spring Harbor

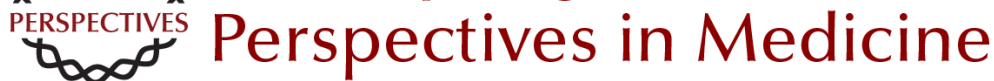

\section{Biomarkers in Multiple Sclerosis}

Anu Paul, Manuel Comabella and Roopali Gandhi

Cold Spring Harb Perspect Med 2019; doi: 10.1101/cshperspect.a029058 originally published online March 2, 2018

\section{Subject Collection Multiple Sclerosis}

Multiple Sclerosis Pathology

Hans Lassmann

Regulatory T Cells: From Discovery to

Autoimmunity

Alexandra Kitz, Emily Singer and David Hafler

The Multiple Roles of B Cells in Multiple Sclerosis and Their Implications in Multiple Sclerosis

Therapies

Rui Li and Amit Bar-Or

Autologous Hematopoietic Stem Cell

Transplantation in the Treatment of Multiple

Sclerosis

Carolina A. Rush, Harold L. Atkins and Mark S.

Freedman

B-Cell Therapies in Multiple Sclerosis

Joseph J. Sabatino, Jr., Scott S. Zamvil and Stephen L. Hauser

Oral Therapies for Multiple Sclerosis Simon Faissner and Ralf Gold

Interferon $\beta$ for Multiple Sclerosis

Dejan Jakimovski, Channa Kolb, Murali

Ramanathan, et al.

Alemtuzumab as Treatment for Multiple Sclerosis Serafeim Katsavos and Alasdair Coles
Natalizumab: Perspectives from the Bench to

Bedside

Afsaneh Shirani and Olaf Stüve

Daclizumab Therapy for Multiple Sclerosis Bibiana Bielekova

Lifestyle and Environmental Factors in Multiple

Sclerosis

Lars Alfredsson and Tomas Olsson

Biomarkers in Multiple Sclerosis

Anu Paul, Manuel Comabella and Roopali Gandhi

The Evolving Mechanisms of Action of Glatiramer

Acetate

Thomas Prod'homme and Scott S. Zamvil

Regulation of Astrocyte Functions in Multiple Sclerosis

Michael A. Wheeler and Francisco J. Quintana

Experimental Autoimmune Encephalomyelitis

(EAE) as Animal Models of Multiple Sclerosis (MS)

Simon Glatigny and Estelle Bettelli

Neurodegeneration in Progressive Multiple

Sclerosis

Graham Campbell and Don Mahad

For additional articles in this collection, see http://perspectivesinmedicine.cshlp.org/cgi/collection/ 